DEPARTAMENTO DE PARASITOLOGÍA

FACULTAD DE CIENCIAS

INSTITUTO DE BIOTECNOLOGÍA

UNIVERSIDAD DE GRANADA

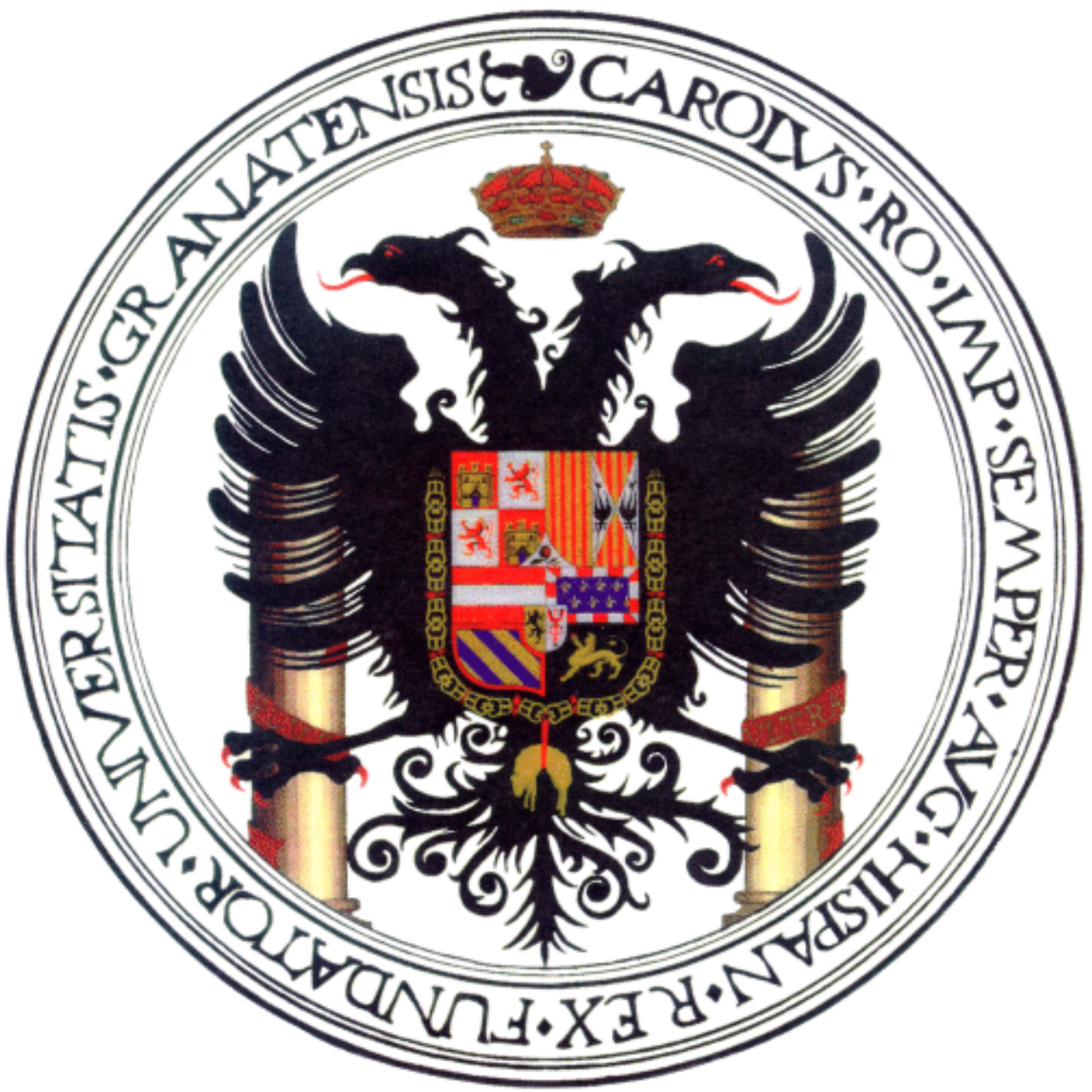

\title{
CARACTERIZACIÓN BIOQUÍMICA Y MOLECULAR DE TRYPANOSOMÁTIDOS AISLADOS DE PERROS EN ESPAÑA
}

JESÚS URBANO ADAMUZ

TUTOR: Prof. Dr. D. Manuel Sánchez Moreno y

Dra. Clotilde Marín Sánchez 

El trabajo de investigación expuesto en la presente memoria titulada: "CARACTERIZACIÓN BIOQUÍMICA Y MOLECULAR DE TRIPANOSOMÁTIDOS AISLADOS DE PERROS EN ESPAÑA", han sido realizados en los laboratorios del Departamento de Parasitología Molecular de la Facultad de Ciencias de la Universidad de Granada, bajo la supervisión del Profesor Dr. D. Manuel Sánchez Moreno y la Dra. D a Clotilde Marín Sánchez.

Granada, Septiembre 2008

Trabajo de investigación presentado para optar al Titulo de MASTER EN BIOTECNOLOGÍA, por el Licenciado en Ciencias Biológicas Jesús Urbano Adamuz.

El director del Trabajo

La codirectora del trabajo

Fdo. Manuel Sánchez Moreno

Fdo. D ${ }^{a}$ Clotilde Marín Sánchez

El licenciado

Fdo. Jesús Urbano Adamuz. 


\section{AGRADECIMIENTOS.}

Quisiera dar la gracias a todas aquellas personas que de algún modo han contribuido a la realización de la presente memoria.

En primer lugar a mi familia por el cariño y apoyo moral, muy especialmente a mi madre, continuo ejemplo de fortaleza y superación, por su comprensión, ánimos y consejos para vencer todos y cada uno de los obstáculos de la vida. Se que sin su apoyo nunca hubiera logrado llegar a la meta. Espero no defraudar la confianza que han depositado en mí.

A mis directores de tesis Prof. Dr. Manuel Sánchez Moreno por brindarme la oportunidad de indagar un poquito en el mundo de la parasitología y por haber depositado en mí su confianza para la realización de este estudio, ofreciéndome así la oportunidad de llevar a cabo la elaboración de esta memoria y por su esfuerzo, entusiasmo, dedicación y amistad durante todo este tiempo.

A la codirectora de esta memoria Dra. Clotilde Marín Sánchez, quien dirigió las correcciones del texto, gracias por tu valiosa ayuda en mis primeros pasos en este complejo mundo científico.

A mis compañeros de laboratorio y a todos los miembros del Departamento de parasitología.

A mis amigos por estar siempre ahí y apoyarme en todo momento. 
Esta memoria está dedicada a Felipe, mi abuelo materno, persona que más quiero. Gracias por haber sido tan noble y luchador y mi referente de comportamiento ante la vida. 


\section{$\underline{\text { INDICE }}$}

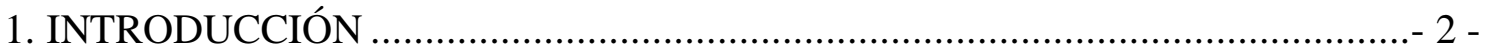

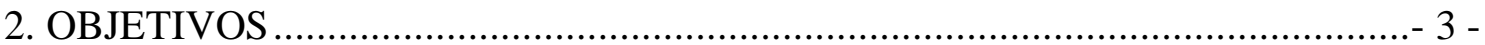

3. ANTECEDENTES.........................................................................................

3.1 CLASIFICACIÓN TAXONÓMICA ………………………………………...- 5 -

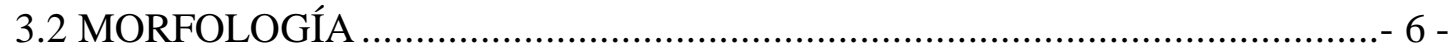

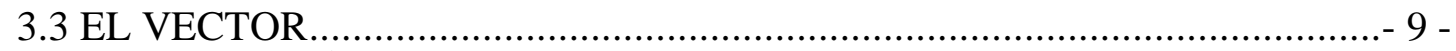

3.4 CICLO BIOLÓGICO .............................................................................- 10 -

3.5 CARACTERIZACIÓN BIOQUÍMICA DE CEPAS …………………..........- 12 -

3.5.1 AGLUTINACION POR LECTINAS................................................... 12 -

3.5.2 ESTUDIOS ISOENZIMÁTICOS. ……………………………………....- 13 -

3.5.3 ESTUDIO DEL ADN DEL KINETOPLASTO....................................... 14 -

4. MATERIAL Y MÉTODOS ………………………………...........................- 16 -

4.1. ORIGEN Y AISLAMIENTO DE LOS PARÁSITOS. ................................... 16 -

4.2. CULTIVO Y OBTENCIÓN DE MASA CELULAR …………...................... 17 -

4.3 CRIOCONSERVACIÓN ………………………...............................- 17 -

4.4 CARACTERIZACIÓN ISOENZIMÁTICA ………………………….......- 18 -

4.4.1 Elección de los sistemas enzimáticos. .......................................................- 19 -

4.4.2 Técnica de isoelectroenfoque................................................................- 19 -

4.5 ANÁLISIS DEL ADNK MEDIANTE ENZIMAS DE RESTRICCIÓN. ........- 22 -

4.5.1 Aislamiento del ADN del Kinetoplasto....................................................- 22 -

4.5.2 Digestión del ADNK con enzimas de restricción. .....................................- 24 -

4.5.3 Amplificación mediante PCR............................................................... 25 -

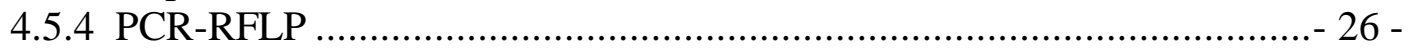

4.5.5 Tratamiento estadístico......................................................................- 26 -

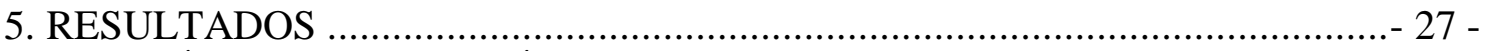

5.1 ANÁLISIS ISOENZIMÁTICO.............................................................- 27 -

5.2 ANÁLISIS DE LOS FRAGMENTOS DEL DNAK OBTENIDOS POR

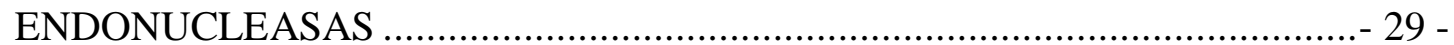

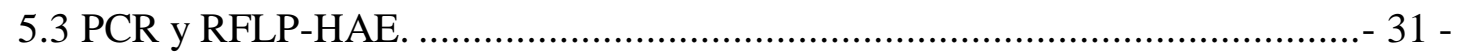

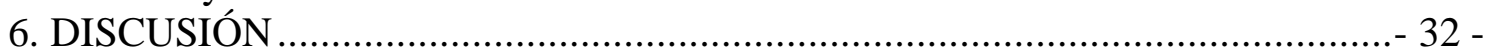

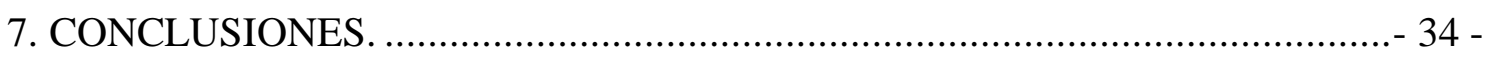

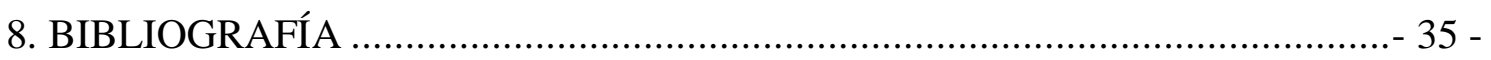




\section{INTRODUCCIÓN}

Las leishmaniasis son un complejo grupo de enfermedades humanas y de otras especies de vertebrados provocadas por la infección por protozoos del género Leishmania y transmitidos por insectos de la subfamilia Phlebotominae (flebótomos). El curso clínico de estas enfermedades, sintomatología, lesiones y pronóstico es muy amplio y abarca desde lesiones cutáneas de curación espontánea hasta daños viscerales letales, ya que, depende por una parte del hospedador y, sobre todo, de la especie de Leishmania responsable.

La Organización Mundial de la Salud concluyó en la $118^{a}$ reunión de su consejo ejecutivo (11 de mayo de 2006) que la leishmaniasis es endémica en 88 países, de los cuales sólo es de declaración obligatoria en 33. Según las estimaciones de la OMS hay 14 millones de personas infectadas, 350 millones de personas en riesgo de contraer la enfermedad y cada año se registran aproximadamente dos millones de nuevos casos.

En España, los casos de leishmaniasis humana afectan principalmente a personas inmunocomprometidas y la mayor parte de los casos que se diagnostican son de leishmaniasis canina (CanL) producida por Leishmania infantum, cuya prevalencia varía desde un 1'6 a un 34'6\%, dependiendo de la región, método de diagnóstico y tipo de muestreo efectuado.

CanL es una de las enfermedades parasitarias más importantes desde el punto de vista zoonótico potencialmente fatal para humanos (niños, ancianos e individuos inmunodeprimidos) y perros, en regiones de Europa, África, Asia y América. La considerable prevalencia de esta infección en la cuenca mediterránea occidental, y particularmente en España, unida al elevado censo canino español, hacen de ella uno de los problemas más relevantes en la patología parasitaria. 


\section{OBJETIVOS}

La identificación y caracterización precisa de las especies es importante puesto que el tratamiento de las enfermedades producidas por estos parásitos puede requerir diferentes regímenes de tratamiento. La caracterización, por tanto, de especies de Leishmanias y Trypanosomas es necesaria para alcanzar los objetivos epidemiológicos, así como para documentar la distribución de las especies y diseñar unas medidas de control apropiadas (Harris y col., 1998).

Debido a lo anteriormente dicho, el objetivo de este trabajo es el de la caracterización de diferentes cepas pertenecientes a los Géneros Leishmania aisladas por el Prof. José María Alunda en perros con leishmaniasis de la comunidad autónoma de Madrid.

La caracterización se ha realizado por diversas técnicas bioquímicas y moleculares que a continuación se citan:

1.- Análisis isoenzimático por isoelectroenfoque en PhastSystem, usando Phast-gel IEF 3-9 (Pharmacia-LKB), utilizando diferentes sistemas enzimáticos: Enzima Málica (ME), Glucosa 6-fosfato deshidrogenasa (G6PDH), Isocitrato deshidrogenasa (IDH), Malato deshidrogenasa (MDH), Glucosa fosfato isomerasa (GPI), superóxido dismutasa (SOD).

2.- Análisis electroforético del $\mathbf{A D N}$ del Kinetoplasto $\left(\mathbf{A D N} \mathbf{N}_{\mathbf{k}}\right)$ usando diferentes endonucleasas de restricción: EcoR I, Msp I, Hae III, BamH I, Hinf I.

3.- Amplificación mediante PCR de determinadas secuencias muy conservadas en el $\mathrm{ADN}_{\mathrm{k}}$ de Tripanosómatidos.

4.- Digestión del producto amplificado con la enzima de restricción HAE III. 


\section{ANTECEDENTES}

La leishmaniasis ya afectaba ancestralmente a las poblaciones andina y selvática antes de la conquista española. Figuras antropomórficas procedentes de las culturas Mochica (330 a. C. -500 d. C.) y Chimú (1000 -1400 d. C.) muestran deformaciones faciales típicas de esta enfermedad. Posteriormente, durante la colonización española, aparecieron las primeras descripciones clínicas de la enfermedad.

En el siglo XVIII Cosme Bueno e Hipólito Ruiz describieron por primera vez el papel de los flebótomos en la transmisión de la enfermedad. Estos autores mencionaron la aparición de una llaga corrosiva de difícil curación, denominada "uta", que aparecía en la cara (Sánchez-Saldaña y col.2004).

En 1756, Alexander Russell describió las llamativas cicatrices de un paciente turco y denominó la enfermedad "Mal de Aleppo" aunque a lo largo de la historia la leishmaniasis ha sido denominada como mal de Jericó, mal de Delhi, salek o uta (Oumeish, 1999).

La enfermedad empezó a conocerse como leishmaniasis a partir de 1901 cuando William Boog Leishman identificó unos organismos ovoides en muestras obtenidas de bazo de un soldado irlandés que había muerto a causa de la llamada fiebre "dum dum".

Estos organismos se describieron inicialmente como tripanosomas hasta que en 1903 Charles Donovan los identificó como otro organismo distinto confirmando los descubrimientos de Leishman. Este nuevo agente se denominó Leishmania donovani.

El cultivo de los promastigotes se hizo posible en 1904 cuando Leonard Rogers incubó un trozo de bazo en medio de cultivo, advirtiendo que los organismos anteriormente observados en las improntas con forma redondeada, adoptaban una morfología alargada. De este modo se logró observar por primera vez a los promastigotes al microscopio óptico.

John Sinton descubrió tras varios años de investigación que la distribución de la enfermedad en India coincidía con la del insecto Phlebotomus argentipes, lo que se 
consideró una información crucial para profundizar en el conocimiento de la leishmaniasis. Tras 14 años de intentos fallidos en el estudio de la transmisión de la enfermedad se descubrió que el parásito sólo puede reproducirse en la hembra del insecto si ésta se alimenta con sangre previamente a una toma de savia vegetal. El tiempo que separe estos dos eventos es clave a la hora de permitir la transmisión del parásito (http://www.who.int/; Gibson, 1983; Oumeish, 1999).

La primera descripción de leishmaniasis humana en España tuvo lugar en 1912 en la provincia de Tarragona al visualizarse leishmanias en una muestra obtenida por punción esplénica de un enfermo sospechoso. Un año más tarde en esa misma zona se descubrió el primer caso de leishmaniasis canina (Botet Fregola y Portús, 1993).

\subsection{CLASIFICACIÓN TAXONÓMICA}

Las leishmaniasis son causadas por parásitos del género Leishmania. A lo largo de la historia ha habido varias clasificaciones, la clasificación más clásica incluía al parásito en el Phylum Protozoa, Clase Zoomastigofora, Orden Kinetoplastida, Suborden Trypanosomatida (Schmidt y Roberts, 1985). La clasificación más reciente de los protozoos propone otra localización taxonómica para el género Leishmania (Cavalier-

Smith, 2003; Moreira y col., 2004):

Reino Protozoa (Goldfuss, 1818)

Subreino Biciliata (Cavalier-Smith 2003)

Infrarreino Excavata (Cavalier-Smith 2002)

Superfilo Discicristata (Cavalier-Smith 1993)

Filo Euglenozoa (Cavalier-Smith 1981)

Subfilo Saccostoma (Cavalier-Smith 1998)

Clase Kinetoplastea (Honigberg 1963)

Subclase Metakinetoplastina (Vickerman 1976)

Orden Trypanosomatida (Kent 1880)

Género Leishmania (Ross 1903)

Subgénero Viannia

Subgénero Leishmania

Género Sauroleishmania 
El tipo de hospedador vertebrado hace posible la diferenciación de los distintos géneros de este suborden: los parásitos de mamíferos pertenecen al género Leishmania y los de reptiles, al género Sauroleishmania (Killick-Kendrick y col., 1986).

Las diferencias en el desarrollo en el interior del vector son utilizadas para definir los subgéneros. Leishmania (Leishmania), que lleva a cabo su desarrollo en las partes superior y media del aparato digestivo (desarrollo suprapilórico), mientras que Leishmania (Viannia) necesita un desarrollo adicional en la parte final del aparato digestivo (desarrollo peripilórico) (Lainson y Shaw, 1987).

Por último, las características morfológicas del parásito no permiten diferenciar las especies de Leishmania.

\subsection{MORFOLOGÍA}

Leishmania es un parásito heteroxeno (con dos hospedadores) que presenta a lo largo de su ciclo vital dos morfologías adaptadas a los distintos ambientes en los que debe sobrevivir (Trager, 1953).

\section{Forma libre, extracelular o promastigote}

El promastigote constituye la forma extracelular que se desarrolla en el aparato digestivo del flebótomo, vector de la enfermedad, y constituye la forma infectante para el hospedador vertebrado. Tiene forma alargada, de 15 a $20 \mu \mathrm{m}$ de longitud y presenta un flagelo libre en su parte anterior que puede llegar a medir el doble de la longitud del cuerpo del parásito (Figura 1). La visión al microscopio electrónico muestra un núcleo central, ribosomas, retículo endoplasmático, aparato de Golgi, una única mitocondria y el kinetoplasto que aparece como un cuerpo electrodenso en la zona anterior (Lofgren, 1950; Crowther y col., 1954). 


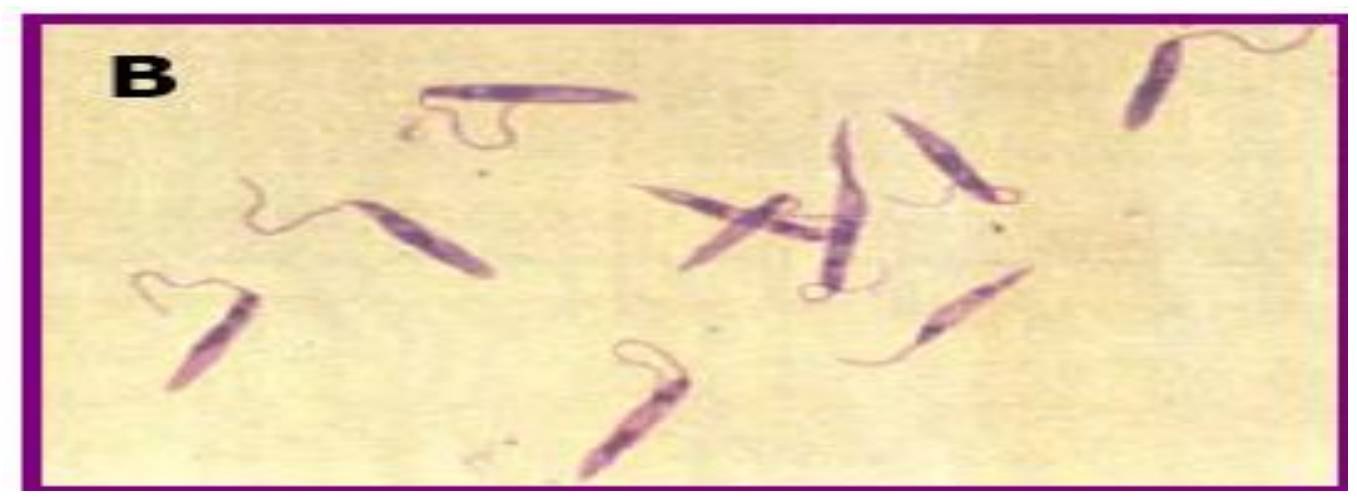

Figura 1. Forma extracelular del parásito (promastigote) teñido con Giemsa. Vista al microscopio óptico (1000x).

\section{Forma aflagelada, intracelular o amastigote}

El amastigote es la forma que se observa en los tejidos parasitados de los hospedadores vertebrados, generalmente en el interior de las células del sistema mononuclear fagocitario (SMF). En el interior de estas células se pueden encontrar los amastigotes englobados en una vacuola (vacuola parasitófora) que se forma tras la fusión del lisosoma y el fagosoma una vez que el parásito ha sido internalizado (Chang y Dwyer, 1978). Los amastigotes son formas ovoides con un tamaño comprendido entre 2 y $5 \mu \mathrm{m}$ de diámetro (Crowther y col., 1954). Estas formas presentan un núcleo central y un kinetoplasto alargado, pudiéndose apreciar la existencia de bolsillo flagelar y un flagelo vestigial (Figura 2) (Chang y Dwyer, 1978; Magill, 1999).
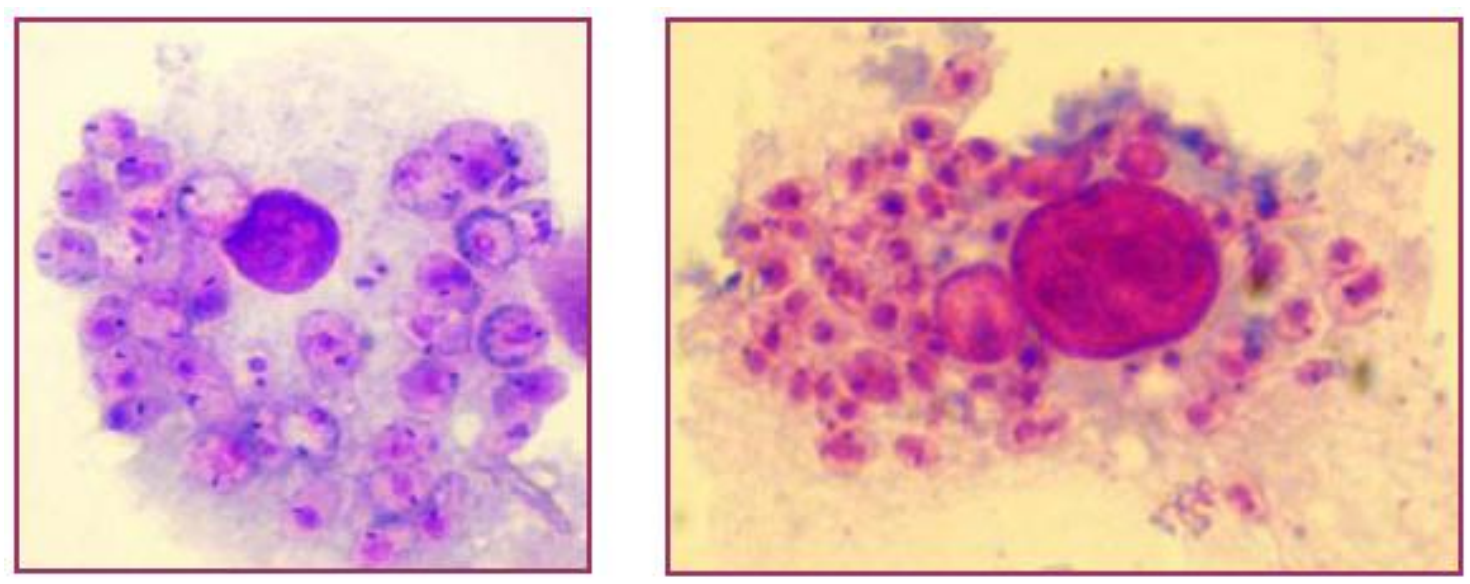

Figura 2. Forma intracelular del parásito (amastigote) en el citoplasma de células macrofágicas de la línea celular J774 teñidas con Giemsa. Vista al microscopio óptico (1000x). 
Durante el desarrollo del parásito en el flebótomo vector, Leishmania adopta varias morfologías intermedias entre la forma flagelada y la aflagelada. Las formas descritas enumeradas por orden de aparición a lo largo de esta transformación son los promastigotes procíclicos (aparecen entre las 24 y 48 tras la ingesta), nectomonas (48 72 horas), leptomonas (4 - 7 días), haptomonas (5 - 7 días) y metacíclicos (7 -14 días), estos últimos son los responsables de la transmisión de la infección al vertebrado (Craig y Faust, 1951; Chang y col., 1990; Kamhawi, 2006).

\begin{tabular}{||c|c|c|c|c||}
\hline MORFOLOGIAS & LONGITUD & FLAGELO & ANCHURA & IMAGEN \\
\hline Amastigote & Ovoide & no & $2-5 \mu \mathrm{m}$ & \\
\hline $\begin{array}{c}\text { Promastigote } \\
\text { procíclico }\end{array}$ & $6^{\prime} 5-11^{\prime} 5 \mu \mathrm{m}$ & $\begin{array}{c}\text { flagelo }< \\
\text { cuerpo }\end{array}$ & variable & \\
\hline $\begin{array}{c}\text { Promastigote } \\
\text { nectomonas }\end{array}$ & $\geq 12 \mu \mathrm{m}$ & variable & variable & \\
\hline $\begin{array}{c}\text { Promastigote } \\
\text { leptomonas }\end{array}$ & $6^{\prime} 5-11^{\prime} 5 \mu \mathrm{m}$ & variable & variable & \\
\hline $\begin{array}{c}\text { Promastigote } \\
\text { haptomonas }\end{array}$ & variable & $\begin{array}{c}\text { Pequeño flagelo } \\
\text { con } \\
\text { forma de disco }\end{array}$ & variable & \\
\hline $\begin{array}{c}\text { Promastigote } \\
\text { metacíclico }\end{array}$ & $\leq 8 \mu \mathrm{m}$ & $\begin{array}{c}\text { flagelo }> \\
\text { cuerpo }\end{array}$ & $\leq 1$ '0 $\mu \mathrm{m}$ & \\
\hline \hline
\end{tabular}

Tabla 1: Clasificación de las distintas formas que adopta Leishmania a lo largo de su ciclo biológico. (Rogers y col, 2002). 


\subsection{EL VECTOR}

Leishmania es transmitida por dípteros nematóceros pertenecientes a la Subfamilia Phlebotominae, en concreto especies de los géneros Lutzomyia en América y Phlebotomus en el Viejo Mundo (Alvar, 1997).

Los flebotomos adultos son dípteros de 1'5 a $3 \mathrm{~mm}$ de longitud, color amarillento y alas lanceoladas. Generalmente estos insectos se alimentan de fuentes naturales de azúcar excepto en el momento de la oviposición, que recurren a la picadura para obtener sangre de mamífero que les proporcione suplementos alimenticios. Cuando los flebotomos hembra se alimentan de un individuo infectado, ingieren los macrófagos infectados con amastigotes. En este momento comienza su papel como vector de la leishmaniasis (Craig y Faust, 1951; Kamhawi, 2006).

La especificidad existente entre el vector y el parásito depende de la composición química de la membrana peritrófica del insecto y las moléculas de superficie del promastigote. La unión de ambos evita la excreción de los parásitos y permite su desarrollo en el interior del aparato digestivo del flebótomo (Pimenta y col., 1994; Sacks y Kamhawi, 2001; Kamhawi, 2006).



Figura 3: Género Phlebotomus 


\subsection{CICLO BIOLÓGICO}

Las leishmanias se localizan y multiplican en las células del sistema fagocítico mononuclear de mamíferos y reptiles sauriomorfos. Su ciclo biológico incluye, además, la presencia de artrópodos vectores, los flebotominos, en cuyo tubo digestivo el parásito se multiplica extracelularmente. De las más de 700 especies descritas de flebotominos, pequeños dípteros de 2-3 mm y con alas peludas y puntiagudas, únicamente unas 70 son vectores probados o sospechosos de transmitir las leishmaniasis. En el Nuevo Mundo todas ellas pertenecen al género Lutzomyia y en el Viejo Mundo al género Phlebotomus.

La mayoría de las leishmaniasis son zoonosis en las que distintas especies animales actúan como reservorio del parásito. En su inicio se trataría de parasitosis de animales salvajes, con la introducción accidental del hombre en el ciclo bio-epidemiológico del parásito (ciclo enzoótico o primario). Al desaparecer el reservorio salvaje del entorno humano, la adopción de animales domésticos susceptibles es el origen de las leishmaniasis de carácter zooantroponótico o secundario. Finalmente, el reservorio animal puede desaparecer y el hombre actuar como único hospedador vertebrado en un ciclo antroponótico o terciario. Así, en el mantenimiento de las leishmaniasis juega un papel fundamental la existencia de mamíferos hospedadores habituales de estos parásitos que constituyen la fuente de partida para su posterior propagación al hombre a través de los flebotomos vectores. Los carnívoros, fundamentalmente los cánidos, y diferentes grupos de roedores ejercen usualmente este papel. Otras especies animales como los osos hormigueros, los perezosos, las zarigüeyas o los damanes pueden actuar también como reservorios en Sudamérica.

El inicio del ciclo en el hospedador vertebrado tiene lugar cuando el flebótomo le inocula con su picadura los promastigotes infestantes o metacíclicos. Una vez llegados al hospedador vertebrado son captados por los macrófagos de la dermis y pasan a su citoplasma donde, englobados en una vacuola parasitófora, el parásito se transforma en la amastigota y se divide activamente por sucesivas divisiones binarias. La multiplicación y desarrollo en los macrófagos finaliza cuando la célula, que contiene unas decenas de parásitos, estalla. Los parásitos libres invaden otros macrófagos de la zona, en los que se repite el proceso multiplicativo, o bien se diseminan directamente a 
través de la piel o de la circulación cutánea hasta alcanzar las mucosas, o son arrastrados por el torrente sanguíneo y linfático, junto a los macrófagos circulantes, para localizarse en territorios orgánicos ricos en células macrofágicas fijas (médula ósea, hígado y bazo principalmente).

El paso del parásito al vector tiene lugar cuando las hembras de los flebotomos se dirigen al hospedador vertebrado con objeto de ingerir sangre para alimentarse y poder desarrollar sus huevos. Las leishmanias se multiplican bajo la forma amastigota a su llegada al tubo digestivo del vector para pasar luego rápidamente a la forma promastigota que se multiplica activamente en su estómago e intestino. Finalmente, y después de pasar por el estadio de paramastigota que también sufre procesos de división binaria, los promastigotes metacíclicos se sitúan en la región bucal o trompa del vector, desde donde pasarán al hospedador vertebrado. Este ciclo general presenta distintas modalidades en las diferentes especies de leishmanias, dependiendo de la zona del intestino en que tiene lugar la presencia y multiplicación de las formas parásitas.

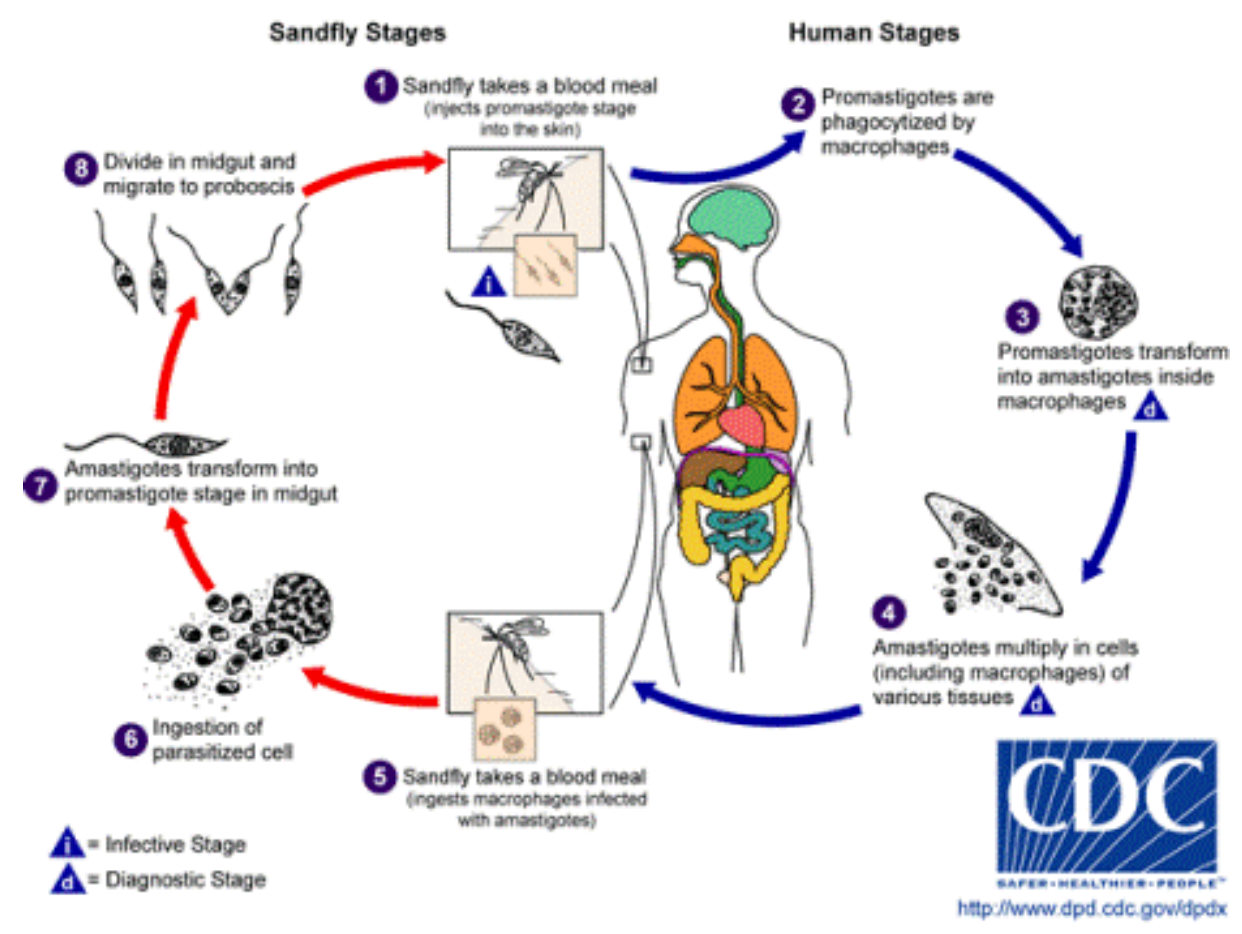

Figura 4: Ciclo biológico del género Leishmania. 


\subsection{CARACTERIZACIÓN BIOQUÍMICA DE CEPAS}

La diferencia en cuanto a la severidad de las enfermedades producidas por tripanosomátidos en el hospedador humano y en otros mamíferos, se ha atribuido al pleomorfismo natural que presentan estas cepas. Esta variabilidad en su comportamiento biológico y la heterogeneidad que presentan, han impedido establecer parámetros adecuados para su clasificación y taxonomía, lo que ha hecho que su caracterización sea una condición necesaria para su estudio y control (Guzmán-Marín y Col., 1999).

La variabilidad intraespecífica de estos parásitos, tradicionalmente ha sido estudiada por medio de curvas de parasitemia, patogenicidad, distribución geográfica, localización tisular y sensibilidad a drogas, pero desgraciadamente la descripción de cepas o especies basada en estos parámetros son insuficientes. Además, es frecuente encontrarnos infecciones mixtas de algunos de estos parásitos.

Estos motivos son los que han llevado a los investigadores a la utilización de otros parámetros, con el fin de identificar a estos parásitos.

\subsubsection{AGLUTINACION POR LECTINAS.}

Un método bioquímico es el estudio de carbohidratos de la superficie de los flagelados del orden Kinetoplástidos, a través de la aglutinación de lectinas.

La regulación en el desarrollo y comportamiento de la expresión de determinados carbohidratos, aún está por resolverse. Sin embargo, hay algunas evidencias de los patrones de la expresión de receptores de lectinas en los parásitos y estos son distintos in vivo e in vitro.

Se ha intentado una caracterización intraespecífica de distintas cepas de T. cruzi de distintas regiones de Suramérica, mediante el estudio de aglutinación con distintas lectinas, observándose una aglutinación común con la Concavalina ensiformis (Con A), 
lectina del cacahuete (PNA) y lectina del germen de trigo (WGA) (Schotteliu, 1984; Piazza y col. 1996). Cuando se comparaba distintas cepas de T. cruzi con T. rangeli, se observaba que la lectina WGA, mostraba una débil o nula aglutinación en cepas de T. rangeli (Steindel y col.1991).

Schottelius observó dos tipos de aglutinación en distintas cepas de T. cruzi: el tipo I o tipo WGA, que aglutinaba con Triticum vulgaris y Aaptos papillata II, y el tipo II o tipo PNA, aglutinaba Arachis hippogaea y Aaptos papillata II (Schottelius, 1984).

En un estudio comparativo de Leishmania donovani aislado de un caso de leishmaniasis dérmica y Leishmania tropica aislado de un caso de leishmaniasis cutánea, presentaba una aglutinación selectiva para la lectina PNA, SRA y WGA, igual que la mayoría de cepas de T. cruzi; sin embargo, Herpetomonas spp. eran positivas para PNA y WGA, mientras que para Bodo no lo era. (Ghosh, 1990). Igualmente en otro estudio la lectina PNA distinguía dos subgéneros de Leishmania (Merezes y col. 1996).

También ha permitido la caracterización de cepas de Leishmania en pacientes con linfoadenopatía, observándose una idéntica aglutinación de las formas promastigotes de estas cepas con cepas de referencia de L. tropica (Ardehali y col 1995).

\subsubsection{ESTUDIOS ISOENZIMÁTICOS.}

La electroforesis de isoenzimas es uno de los métodos empleados para detectar diferencias entre enzimas con propiedades catalíticas similares pero con distinta estructura molecular, lo que permite agrupar cepas de acuerdo a sus perfiles isoenzimáticos, que reciben el nombre de zimodemos (Rodríguez y col. 1998).

En 1979 (Rassam y col.) consiguieron caracterizar 43 stocks del género Leishmania aislados de diferentes órganos de diferentes pacientes, determinando que 37 de estos aislados se podían clasificar como $L$. major y los 6 restantes como pertenecientes a $L$. tropica. Desde esta fecha hasta la actualidad, han sido numerosos los autores que 
utilizando esta técnicas han caracterizados diferentes aislado del género Leishmania (Lucas y col. 1994; Travi y col. 1994; Ibrahim y col. 1995).

Esta técnica también es útil para estudiar subpoblaciones clonadas de una cepa, las cuales presentan diferencias entre sus patrones isoenzimáticos respecto a la cepa patrón, demostrando que las cepas del parásito pueden ser heterogéneas en su composición (Penin y col. 1998).

También se ha demostrado la existencia de patrones isoenzimáticos diferentes según la etapa del ciclo biológico en que se encuentra el parásito, según el número de bandas, posición e intensidad de las mismas, dando lugar a zimodemas distintas. Esto puede ser parte del proceso regulatorio asociado con cambios metabólicos y morfológicos del parásito. (Bogliolo y col. 1986; Lewicka y col. 1995; Higo y col. 2000).

\subsubsection{ESTUDIO DEL ADN DEL KINETOPLASTO.}

Además de los métodos bioquímicos existen otros métodos para caracterizar tripanosomátidos, como es el análisis del ADN del kinetoplasto (ADNk). Las secuencias de maxicírculos son relativamente conservadas, mientras que las secuencias de minicírculos son muy heterogéneas y se considera para un mejor entendimiento en la rápida evolución de estos parásitos. (Brown y col. 1997).

La división del ADNk por endonucleasas de restricción, produce fragmentos que se visualizan en geles de poliacrilamida por medio de isoelectroenfoque y son característicos de los principales tripanosomátidos (Morel y col. 1980).

Se conoce bastante sobre el análisis por las enzimas de restricción del ADNk de $T$. cruzi, pero está mucho más restringido este análisis en el ADNk de T. rangeli., analizaron el ADNk de seis cepas simpátricas de T. cruzi. Los patrones de EcoRI son altamente heterogéneos, característica de la región de minicírculo de T. cruzi y contracta con los perfiles de los fragmentos de restricción homogéneos de T. rangeli.

Existen otras técnicas moleculares tales como marcadores nucleares que codifican ARN ribosomal 143 y el miniexón (Solito y col. 1996 y 1998), ARN spliced leader y genes 
promotores del ARN ribosómico (Nunes y col. 1997), se utilizan para diagnosis diferencial de los tripanosomatidos. Así, la amplia variabilidad del tamaño del dominio D7 de la subunidad mayor del ARN ribosómico es usada para la detección de distintas especies. (Fernándes y col. 1998). Estos marcadores genotípicos mostraban una correlación discreta con las características fenotípicas previamente determinada por isoenzimas.

En los últimos años se han utilizado técnicas de amplificación del ADN y de la subunidad pequeña del ARN ribosómico 188 para caracterización de especies, para estimar la distancia fenotípica entre cepas (Oliveira y col. 1998), así como para diagnóstico específico (Morel y col.1980). 


\section{MATERIAL Y MÉTODOS}

\subsection{ORIGEN Y AISLAMIENTO DE LOS PARÁSITOS.}

Las ocho nuevas cepas de Leishmania fueron aisladas de perros en la provincia de Madrid por el grupo del profesor José María Alunda en el Laboratorio de Salud Animal,

Escuela de Veterinaria (Madrid, España). Incluimos en el estudio, tres cepas de referencia de $L$. (L.) infantum, pertenecientes al zimodema MON-1: MCAN/ES/00/UCM1, MCAN/ES/00/UCM6 y MCAN/ES/00UCM11 (Bulle y col., 2002).

Las nuevas cepas caracterizadas en este estudio fueron aisladas de sangre de perros enfermos de leishmaniasis. Para lo que, en primer lugar se le realizo un frotis con una muestra de sangre sobre un porta que tras ser fijado y teñido se observa al microscopio en busca de formas amastigotas en el interior de las células del SMF (Sistema Mononuclear Fagocitario). Las cepas aisladas se cultivaron como formas promastigotas en medio bifásico Novy-MacNeal-Nicolle (NNN) con una fase líquida de medio MTL (Medium for Trypanosome Liquid (Ruiz-Pérez y col., 1986) suplementado con un 10\% de SBFI (suero bovino fetal inactivado a $56^{\circ} \mathrm{C}$ durante 30 minutos) a $28^{\circ} \mathrm{C}$.

Como modo de precaución en todas las fases iniciales de los cultivos es necesaria la adición de una mezcla antibiótica y antimicótica para evitar contaminación por bacterias, hongos y levaduras.

Los cultivos exentos de contaminantes fueron clonados y transferidos a frascos de cultivo celular de $25 \mathrm{ml}$ (Roux) con medio de cultivo monofásico líquido MTL suplementado con un $10 \%$ de SBFI a $28^{\circ} \mathrm{C}$. 


\subsection{CULTIVO Y OBTENCIÓN DE MASA CELULAR}

El cultivo in vitro y mantenimiento de las nuevas cepas se realizó en medio MTL al $10 \%$ de SBFI en frascos de $25 \mathrm{~cm}^{2}$ (Roux) a $28^{\circ} \mathrm{C}$, partiendo de una concentración de $5.10^{4} \mathrm{cé} \mathrm{l} / \mathrm{ml}$.

La obtención de masa celular necesaria para llevar a cabo el estudio de caracterización bioquímica y molecular se alcanzó cuando la densidad celular fue aproximadamente de $2.10^{7} \mathrm{cé} \mathrm{l} / \mathrm{ml}$, mediante contaje en la cámara hemocitométrica de Neubauer. Esto es, aproximadamente $500 \mathrm{ml}$ de medio de cultivo de cada aislado cultivado libre de cualquier tipo de contaminación. Este volumen de cultivo se centrifugó en ciclos de $2500 \mathrm{rpm}$ durante 10 minutos, finalmente se procedió al lavado del pellet o precipitado obtenido con tampón PBS, centrifugándolo 2 veces en las mismas condiciones que anteriormente. Desechamos el sobrenadante y nos quedamos con el pellet limpio de medio de cultivo que se guardó a $-20^{\circ} \mathrm{C}$ hasta su utilización

\subsection{CRIOCONSERVACIÓN}

Mediante la congelación en nitrógeno líquido logramos mantener una línea celular durante mucho tiempo. Para deshidratar la célula usamos un agente crioprotector como es el dimetilsulfóxido o glicerol, que es un soluto de bajo peso molecular y por ello permeable a la membrana plasmática que protegen a esta congelación. Cuando en el medio extracelular ocurre la cristalización se forma hielo puro, dejando los solutos progresivamente más concentrados en la fracción liquida a medida que el cambio de fase progresa. De esta manera las células en suspensión deben deshidratarse para mantener el equilibrio osmótico con un medio extracelular cada vez más hipertónico y permaneciendo así congeladas (Bosio, 2001).

Hay que indicar que la densidad de crecimiento óptima para congelar los parásitos es de aproximadamente $1.10^{6} \mathrm{cél} / \mathrm{ml}$. Es importante también que en el momento de la congelación la temperatura descienda de forma gradual, evitando cambios bruscos que 
pueden llegar a romper las células. Para que esto sea posible se guardan en un contenedor Cryo $1^{\circ} \mathrm{C}$ (Nalgene) que contiene alcohol isopropílico, de modo que la temperatura desciende a una velocidad de $1^{\circ} \mathrm{C} / \mathrm{min}$.

\section{PROCEDIMIENTO:}

(Todo este procedimiento debe hacerse en condiciones de esterilidad, evitando de esta forma posibles contaminaciones por bacterias, hongos o levaduras)

1. Centrifugamos nuestro cultivo de parásitos en fase logarítmica de crecimiento a 1500 rpm durante 10 minutos.

2. Retiramos el sobrenadante y añadimos al pellet $5 \mathrm{ml}$ de Medio de Congelación (medio de cultivo más $10 \%$ de glicerol estéril), resuspendiendo dicho pellet.

3. Repartimos las células en medio de congelación en viales de 1,5 ml de capacidad.

4. Introducimos los viales en un tanque de isopropílico y éste a su vez, en el congelador de $-80^{\circ} \mathrm{C}$ durante 24 horas.

5. Pasado este tiempo, guardamos nuestros viales en Nitrógeno líquido indefinidamente.

Por último, indicar que la recuperación de los parásitos se obtiene descongelación rápida, en una estufa de $37^{\circ} \mathrm{C}$, con el fin de evitar destruir las estructuras intracelulares, aun así, alrededor del 10\% de los parásitos muere en este proceso.

\subsection{CARACTERIZACIÓN ISOENZIMÁTICA}

Las isoenzimas, enzimas que catalizan el mismo sustrato, tienen una migración diferente en la electroforesis y son el reflejo directo del polimorfismo del ADN. Las diferencias de migración observadas, traducen diferencias en cuanto a la carga neta de las proteínas estudiadas. Estas diferencias de cargas son el reflejo de la estructura 
primaria (secuencias de aminoácidos) de las proteínas en cuestión, la cual depende directamente de la secuencia de ADN que codifica la proteína.

\subsubsection{Elección de los sistemas enzimáticos.}

Se han elegido los siguientes sistemas enzimáticos por su claridad de revelación e interpretación y por su significación en el metabolismo energético de los tripanosomátidos presentes e este estudio: Enzima málico (EM) [E.C.1.1.1.40], Malato deshidrogenasa (MDH) [E.C.1.1.1.37], Isocitrato deshidrogenasa (IDH) [E.C.1.1.1.42], Glucosa fosfato isomerasa (GPI) [E.C.5.3.1.9], Glucosa 6 fosfato deshidrogenasa (G6PD) [E.C.5.3.1.9] y Superóxido dismutasa (SOD) [E.C.1.15.1.1], esta última se determino siguiendo el protocolo de Paoletti y Mocali (1990).

\subsubsection{Técnica de isoelectroenfoque.}

La electroforesis de proteínas en geles con una matriz de poliacrilamida, comúnmente denominada electroforesis en poliacrilamida (PAGE, "polyacrilamide gel electrophoresis) es sin duda una de las técnicas más usadas para caracterizar mezclas complejas de proteínas. Además, es un método conveniente, rápido y económico a nivel de muestra pues se requieren sólo cantidades del orden de microgramos de proteína.

Las proteínas presentan una carga eléctrica neta si se encuentran en un medio que tenga un $\mathrm{pH}$ diferente al de su punto isoeléctrico y por eso tienen la propiedad de desplazarse cuando se someten a un campo eléctrico. La velocidad de migración es proporcional a la relación entre las cargas de la proteína y su masa.

La electroforesis por isoelectroenfoque o electroenfoque se basa en el desplazamiento de las moléculas en un gradiente de $\mathrm{pH}$. Las moléculas anfotéricas, como los aminoácidos, se separan en un medio en el que existe una diferencia de potencial y un gradiente de pH. La región del ánodo (+) es ácida y la del cátodo (-) es alcalina. Entre ambos se establece un gradiente de $\mathrm{pH}$ tal que las moléculas que se han de separar tengan su punto isoeléctrico dentro del rango. La migración les conducirá a una región donde el pH coincidirá con su pI, tendrán una carga neta nula (forma zwiterion) y se detendrán. 
Los flagelados obtenidos según se ha descrito en el apartado 3.2 fueron resuspendidos a una densidad de $2.10^{7}$ células/ml en $2 \mathrm{ml}$ de una solución hipotónica, compuesta por $2 \mathrm{mM}$ ditiotreitol, $2 \mathrm{mM}$ ácido n-aminocaproico y 2mM EDTA (Golfrey y Kilgour, 1976). Para asegurar la lisis de estos organismos se sometieron a ultrasonidos en un aparato sonicador (Vibra Cell, Sonics y Materials Inc Danubury CT, USA), sumergiendo la sonda $1 \mathrm{~cm}$ en el liquido en intervalos de 30 segundos 3 veces, teniendo un periodo de reposo de 1 minuto entre cada intervalo.

Una vez lisados los parásitos fueron centrifugados a $3500 \mathrm{rpm}$ durante 10 minutos a $4^{\circ}$ C (Sánchez Moreno y col. 1992). El proceso fue continuado con el sobrenadante que se desalinizó por una columna P-10 (Sphadex G-25) (GE Healthcare) para eliminar sales que pueden causar problemas en el estudio de las enzimas.

Seguidamente se determinó la concentración de proteínas mediante el método Bradford (Bradford, 1976) y se hicieron alícuotas en tubos ependorff a una concentración entre 10-20 $\mu \mathrm{g} / \mu \mathrm{l}$ de proteína y se almacenaron $\mathrm{a}-20^{\circ} \mathrm{C}$ hasta su utilización.

Las muestras se separaron mediante isoelectroenfoque usando Phast-System (Pharmacia) y geles de poliacrilamida de rango de pH (pI) 3-9 (Phas-gel IEF-3-9) suministrados por la misma casa comercial. A los geles se les realizó un preenfoque bajo las siguientes condiciones: $2000 \mathrm{mV} ; 2,5 \mathrm{~mA} ; 3,5 \mathrm{~W} ; 75 \mathrm{Vh}$. Aunque el punto de aplicación de la muestra no es crítico pues las moléculas siempre se desplazan hacia la región de su pI, con objeto de conseguir una mejor visualización de los resultados aplicamos la muestra de la solución proteica $(15 \mu \mathrm{g} / \mu \mathrm{l})$ según la enzima a revelar en la parte ácida, básica o central del gel.

Tras esto se cambiaron las condiciones para que las proteínas de la muestra se separaran en el gel conteniendo los anfolitos (el corrido se realizó a $2000 \mathrm{~V} ; 2,5 \mathrm{~mA} ; 3,5 \mathrm{~W} ; 15$ Vh, con un número total de $410 \mathrm{Vh})$.

Una vez finalizada la electroforesis, los geles fueron colocados en una placa de Petri, donde se llevó a cabo el proceso de revelado siguiendo los procedimientos descritos por Ben Abderrazak y col. (1993) que se reflejan en la siguiente tabla. 


\begin{tabular}{|c|c|c|}
\hline ENZIMA & "TAMPÓNDE REACCIÓN & " SOLUCIÓN DE TINCIÓN \\
\hline GPI & $1(1 / 4)$ & $\begin{array}{l}\text { 10mg fructosa } 6 \text { fosfato, } \\
5 \mathrm{UI} \text { glucosa } 6 \text { fosfato } \\
\text { deshidrogenasa,50 } \mathrm{mgr} \\
\mathrm{MgCl}_{2}, 5 \mathrm{mg} \text { NADP, } 1,2 \\
\text { MTT,3mg PMS. }\end{array}$ \\
\hline IDH & $2(1 / 10)$ & $\begin{array}{l}\text { 10mg D-L-ácido } \\
\text { isocítrico,50 mgr } \mathrm{MgCl}_{2}, 5 \\
\text { mg NADP,1,2 MTT,3mg } \\
\text { PMS. }\end{array}$ \\
\hline $\mathrm{MDH}$ & $2(1 / 10)$ & $\begin{array}{l}\text { 0,9ml ácido málico } \mathrm{pH}=7.0 \\
\text { (D-L-ácido málico), } 4 \mathrm{mg} \\
\text { NAD,1,2 MTT,3mg PMS. }\end{array}$ \\
\hline EM & $1(1 / 4)$ & $\begin{array}{l}\text { 0,6ml ácido málico } \mathrm{pH}=7.0 \\
\text { (D-L-ácido málico),50 mgr } \\
\mathrm{MgCl}_{2}, 5 \mathrm{mg} \text { NADP, } 1,2 \\
\text { MTT,3mg PMS. }\end{array}$ \\
\hline G6PDH & $1(1 / 4)$ & $\begin{array}{l}\text { 5mg fructosa } 6 \text { fosfato, ,50 } \\
\text { mgr } \mathrm{MgCl}_{2}, 5 \mathrm{mg} \text { NADP, } \\
\text { 1,2 MTT,3mg PMS. }\end{array}$ \\
\hline
\end{tabular}

El tampón de reacción: indica la dilución del tampón 1 y 2 para un volumen total de 10ml. Tampón 1 (1 M tris-HCL pH 7.0), Tampón 2 (1 M tris-HCL pH 8.0).

Para determinar la actividad SOD se utilizó el revelado negativo donde se determina la inhibición de la reducción del azul del nitrotetrazolio (NBT) fotoquimicamente según lo descrito por Beyer y Fridovich (1987). Los geles fueron sumergidos en $10 \mathrm{ml}$ de una solución stock (27 ml de tampón fosfato potásico $50 \mathrm{mM}$, pH 7.8; 1,5 ml L-metionina (300 mg/10ml), 1ml de NBT (14,1 mg/10ml) y 0,75 ml de 1\% (v/v) Tritón X-100), adicionándole $100 \mu \mathrm{l}$ de una solución de riboflavina $(4,4 \mathrm{mg} / 100 \mathrm{ml})$, incubándose bajo luz a temperatura ambiente hasta la aparición de las bandas. 


\subsection{ANÁLISIS DEL ADNK MEDIANTE ENZIMAS DE RESTRICCIÓN.}

\subsubsection{Aislamiento del ADN del Kinetoplasto.}

El $\mathrm{ADN}_{\mathrm{K}}$ fue aislado según el procedimiento de Gonçalves y col. (1984), que a continuación se detalla:

1- Se toma una concentración de aproximadamente $5.10^{9}$ células obtenidas como se ha descrito anteriormente.

2- Resuspendemos el pellet en 2,5 ml de tampón de lisis (10 mM Tris HCL pH 8.0, $100 \mathrm{Mm}$ EDTA, pH 8.0, $20 \mu \mathrm{g} / \mathrm{ml}$ Pancreatic Rnase y $0.5 \%$ SDS) y una vez resuspendidos se adicionan $100 \mu \mathrm{l}$ de proteinasa $\mathrm{k}(20 \mathrm{mg} / \mathrm{ml})$ y $100 \mu \mathrm{lde} \mathrm{N}$ lauril-sarcocine al $30 \%$ (3gr/10ml). Dejamos incubando 3 horas a $60^{\circ} \mathrm{C}$ o bien toda la noche a $60^{\circ} \mathrm{C}$ en agitación suave.

3- Centrifugamos 3 horas a $15000 \mathrm{rpm} \mathrm{y} 4^{\circ} \mathrm{C}$. En el sobrenadante tenemos el ADN nuclear y en el pellet el ADN del kinetoplasto, a continuación decantamos y eliminamos el sobrenadante(o guardar si interesa el $\mathrm{ADN}_{\mathrm{N}}$ ) teniendo la precaución de que no resuspender el precipitado.

4- Resuspendemos nuevamente el precipitado obtenido en la primera centrifugación (ADNk) en 10 ml de Tampón TE (10 mM Tris-HCL, pH 8.0, $1 \mathrm{mM}$ EDTA).

5- Se vuelve a centrifugar 3 horas a $15000 \mathrm{rpm}$ y $4^{\circ} \mathrm{C}$.

6- Volvemos a decantar eliminando nuevamente el sobrenadante y nos quedamos con el pellet (asegurarse de que eliminamos todo el sobrenadante, si fuera necesario limpiar las paredes del tubo con papel para eliminar los posibles restos de sobrenadante que haya podido quedarse adherido).

7- Resuspender el pellet en un volumen mínimo de $300 \mu$ l de Tampón TE y pasar a ependorff en alícuotas de $150 \mu 1$. 
8- Añadimos un volumen igual $(150 \mu \mathrm{l})$ de fenol cloroformo alcohol-isoamílico (1:1) saturado con $50 \mathrm{mM}$ Tris $\mathrm{pH} 7,4100 \mathrm{mM} \mathrm{NaCl}$.

9- Mezclamos la mezcla por inversión suave en varios tiempos y centrifugamos durante 2 minutos a $\mathrm{T}^{\mathbf{o}}$ ambiente en microfuga de alta velocidad (13200 rpm).

10- Extraemos la parte acuosa superior (sobrenadante) y la pasamos a otro Ependorff con cuidado de no coger parte de la interfase.

11- Repetir el proceso 1 veces más, sustituyendo el fenol cloroformo alcoholisoamílico por tampón TE desde el punto 8 juntando toda la parte acuosa en mismo Ependorff.

12- Medir el volumen recogido de la parte acuosa y añadirle 3 volúmenes más de éter-etílico saturado con agua (1:1).

13- Centrifugamos 2 minutos y quitamos el éter (fase superficial) por aspiración.

14- Dejar a $37^{\circ} \mathrm{C}$ durante 30 minutos para permitir que se evapore todo el éter (el tiempo puede sufrir variaciones, lo dejaremos hasta que se haya evaporado todo el éter, es recomendable dejarlo varias horas evaporando).

15- Medir el volumen que tenemos juntándolo todo en un solo tubo calibrado.

16- Añadir 3 volúmenes de etanol absoluto (muy frío), tapamos con papel parafilm y agitamos.

17- Dejar 12 horas como mínimo a $-20^{\circ} \mathrm{C}$, para que precipite todo el $\mathrm{ADN}_{\mathrm{k}}$.

18- Centrifugar 30 minutos a $13200 \mathrm{rpm}$ en microfuga de alta velocidad. Tras la centrifugación eliminaremos el sobrenadante (lo decantamos) y continuamos hasta que no nos quede mas volumen (el pellet que se observa es ya ADNk). 
19- Resuspendemos muy bien el pellet en $120 \mu \mathrm{l}$ de tampón TE y se deja en reposo a $4^{\circ} \mathrm{C}$ durante 30 minutos para permitir que se hidrate el ADNk.

20- Medir la concentración de $\mathrm{ADN}_{\mathrm{K}}$ en espectrofotómetro a 260 y $280 \mathrm{~nm}$.

\section{MEDIDA DE LA CONCENTRACIÓN DE ADN}

1- Tomar $20 \mu \mathrm{l}$ de $\mathrm{ADN}_{\mathrm{K}}$ y le añadimos $480 \mu \mathrm{l}$ de TE (preparamos un blanco con $500 \mu \mathrm{l}$ de TE), a continuación medir la concentración $\left(\mu \mathrm{g} / \mu \mathrm{l} \mathrm{ADN}_{\mathrm{K}}\right)$ en espectrofotómetro a $260 \mathrm{~nm}$ y a $280 \mathrm{~nm}$ y anotar los resultados.

2- Calcular la cantidad de ADNk presente utilizando la siguiente relación.

\section{$A D N k=A 260 \times$ dilución $25 \times 0,05 \mu g / \mu l$}

$$
A D N k=A_{260} \times 1,25 \mu g / \mu l
$$

\subsubsection{Digestión del ADNK con enzimas de restricción.}

Las endonucleasas son enzimas que cortan el ADN en secuencias específicas dentro de la molécula (contario a las exonucleasas, que digieren a las moléculas de ADN por sus extremos) (Granner, 1992). Estas enzimas se encuentran en una amplia variedad de especies bacterianas y su función biológica consiste en reconocer y romper el ADN ajeno que pueda penetrar en la célula (por ejemplo, ADN procedente de bacteriófagos).

De esta forma estas endonucleasas restringen el funcionamiento de los fagos en el interior de la bacteria, motivo por el cual originalmente se les llamó enzimas de restricción. El ADN propio, sin embargo, no es digerido porque las bacterias cuentan con un mecanismo que impide que esto ocurra. Así, al conferir la naturaleza este sistema de defensa a las bacterias, otorgó también a los científicos un arsenal de enzimas altamente específico para manipular el ADN (Granner y col., 1996). 
Una vez aislado el $\mathrm{ADN}_{\mathrm{K}}$ fue digerido con cinco endonucleasas de restricción (EcoRI, MspI, HindIII, HinfI y BamHI), bajo las condiciones y tampones recomendados por la casa comercial suministradora (Boehringer $\left.{ }^{\circledR}\right)$. La digestión de $1 \mu \mathrm{l}\left(3 \mu \mathrm{g} \mathrm{ADN}_{\mathrm{K}} / \mu \mathrm{l}\right) \mathrm{de}$ cada una de las muestras se realizó a $37^{\circ} \mathrm{C}$ durante 3 horas y los productos resultantes de las mismas fueron sometidos a electrofóresis en geles de agarosa al 1,3\% en tampón TAE 1X, (0,04 M Tris-Acetato,0.001 M EDTA, pH 8.0) tal y como describieron Riou y Yot (1977).El tamaño de los fragmentos obtenidos fue determinado por comparación de sus movilidades con las del marcador utilizado de $1 \mathrm{~Kb}$ DNA ladder (Gibco BRL). Los geles fueron teñidos con bromuro de etidio $(10 \mu \mathrm{g} / \mathrm{ml}$ durante $10 \mathrm{~min})$. Finalmente el resultado fue fotografiado bajo luz ultravioleta con una cámara Olympus Camedia digital camera, C-4000 Zoom.

\subsubsection{Amplificación mediante PCR.}

El DNA $A_{k}$ extraído fue sometido al análisis PCR que amplifica una parte de los genes que codifican la subunidad pequeña del $\mathrm{RNA}_{\mathrm{r}}$ de Leishmania (Van Eys y col., 1992). Se usaron unos primers específicos para leishmanias, R174 (5GGTTCCTTTCCTGATTTACG-3) y R798 (5-GCCGGTAAAGGCCGAATAG-3) que generan unos fragmentos de aproximadamente 600 pb. Las reacciones de amplificación fueron realizadas en un volumen final de $50 \mu 1$ de mezcla de reacción que comprende 5 $\mu l$ de $\mathrm{DNA}_{\mathrm{k}}$ aislado, $4 \mathrm{mmol} / \mathrm{L} \mathrm{MgCl} 2,250 \mu \mathrm{mol} / \mathrm{L}$ de $\mathrm{NTP}_{\mathrm{d}}, 1 \mu \mathrm{mol} / \mathrm{L}$ de cada primers y $1 \mathrm{U}$ de DNA polimerasa. Las reacciones fueron realizadas en un MyCycler ${ }^{\mathrm{TM}}$ Termal Cycler (BioRad $®)$ en ciclos de, $95^{\circ} \mathrm{C}$ durante 5 minutos, 35 ciclos de los siguientes cuatro pasos ( $60^{\circ} \mathrm{C} / 30$ seg.s, $72^{\circ} \mathrm{C} / 30$ seg.s, $95^{\circ} / 30$ seg.s, $60^{\circ} \mathrm{C} / 30$ seg.), y finalmente $72^{\circ} \mathrm{C}$ durante 10 minutos. Tanbién fue ensayado un control negativo, sin $\mathrm{ADN}_{\mathrm{k}}$. Seguidamente, los productos de amplificación fueron sometidos a electroforesis en gel de agarosa al $1.3 \%$ que contiene $0.5 \mu \mathrm{g} / \mathrm{ml}$ de bromuro de etidio. 


\subsubsection{PCR-RFLP}

PCR-RFLP kDNA se hizo según el protocolo descrito por (Volpini y col., 2004). Se cogieron $5 \mu \mathrm{ldel}$ producto amplificado por PCR a los que se les añadió 1U HaeIII (Boehringer-Ingelheim, Barcelona, España) y se incubarón a $37^{\circ} \mathrm{C}$ durante 3 horas. El producto digerido fue sometido a electroforesis en gel de agarosa al $1.3 \%$ que contiene $0.5 \mu \mathrm{g} / \mathrm{ml}$ de bromuro de etidio.

\subsubsection{Tratamiento estadístico.}

El tratamiento estadístico se basó en el análisis Cluster Jerárquico por individuos, seleccionando la distancia Euclídea al cuadrado como la base para medir las asociaciones entre individuos. La distancia Euclídea al cuadrado fue calculada según los procedimientos de agrupación siguientes: el acoplamiento simple ( $\mathrm{R}$ K 0.7355), el acoplamiento medio entre grupos ( $\mathrm{R} \mathrm{K}$ 0.7518), el acoplamiento medio (R K 0.7726), el método del centroide (R K 0.7586), el método de mediana ( R K 0.7204), y el método de Sala (R K 0.7570). El coeficiente cofenético ( $\mathrm{R} \mathrm{k}$ ) mide el grado de distorsión entre relaciones, es decir, las distancias originales entre individuos y aquellos que quedan al final del análisis. El que presentaba la correlación cofenética más alta fue escogido como el método óptimo.

En los procedimientos de selección el acoplamiento medio entre grupos fue considerado, usando el coeficiente $\mathrm{R} \mathrm{K}$ de $\mathrm{R}$, el cual, es un índice de semejanza entre clasificaciones. Este análisis fue hecho con el programa StatGraphics, versión 5.0. 


\section{RESULTADOS}

\subsection{ANÁLISIS ISOENZIMÁTICO.}

Mediante el empleo de seis sistemas enzimáticos hemos podido diferenciar entre sí a la mayoría de estos aislados estudiados. Las enzimas fueron separadas por isoelectroenfoque usando un Phas-System (Pharmacia) y geles de poliacrilamida (Material y Métodos apartado 3.3).

En la Figura 5 se muestran los perfiles isoenzimáticos correspondientes a los seis sistemas enzimáticos (ME; G6PDH; GPI; IDH; MDH y SOD) que se caracterizan por el número de bandas y por su movilidad.

En general, podemos decir que estos seis sistemas revelaron pocas variaciones en cuanto al número de bandas y a su movilidad electroforética. Así que podemos identificar 2 grupos del conjunto de isoenzimas estudiadas, excepto en tres sistemas enzimáticos (Figura 5.A, 5.D, 5.F): Enzima Málico (EM); Isocitrato deshidrogenasa (IDH); Superóxido dismutasa (SOD).

Las cepas de referencia tienen el mismo número de bandas y la misma movilidad electroforética para los sistemas enzimáticos Isocitrato deshidrogenasa (IDH) y Superóxido dismutasa (SOD) (Figura 5.D y 5.G. Líneas 5,9 y 11). La UCM 6 y UCM 1 comparten el mismo modelo en el Enzima Málico (EM) y en la Malato deshidrogenasa (MDH) (Figura 5.A y 5.F. Líneas 5, y 11), mientras que la UCM 1 y la UCM 11 tienen el mismo modelo para los sistemas enzimáticos Glucosa 6-fosfato deshidrogenasa (G6PDH) y Glucosa fosfato isomerasa (GPI) (iFgura 5.B y 5.C. Líneas 11, y 9). El nuevo aislado UCM 45 se diferencia de todos los otros aislados en los sistemas Enzima Málico (ME) y Malato deshidrogenasa (MDH) (Figura 5.A hasta la 5.F. Líneas). Igualmente, el aislado UCM 17 es diferente para la enzima Málico (EM), (figura 5.A, línea 2), y la UCM 21 es diferente para la isocitrato deshidrogenasa (IDH), (figura 5.D, línea 7). 

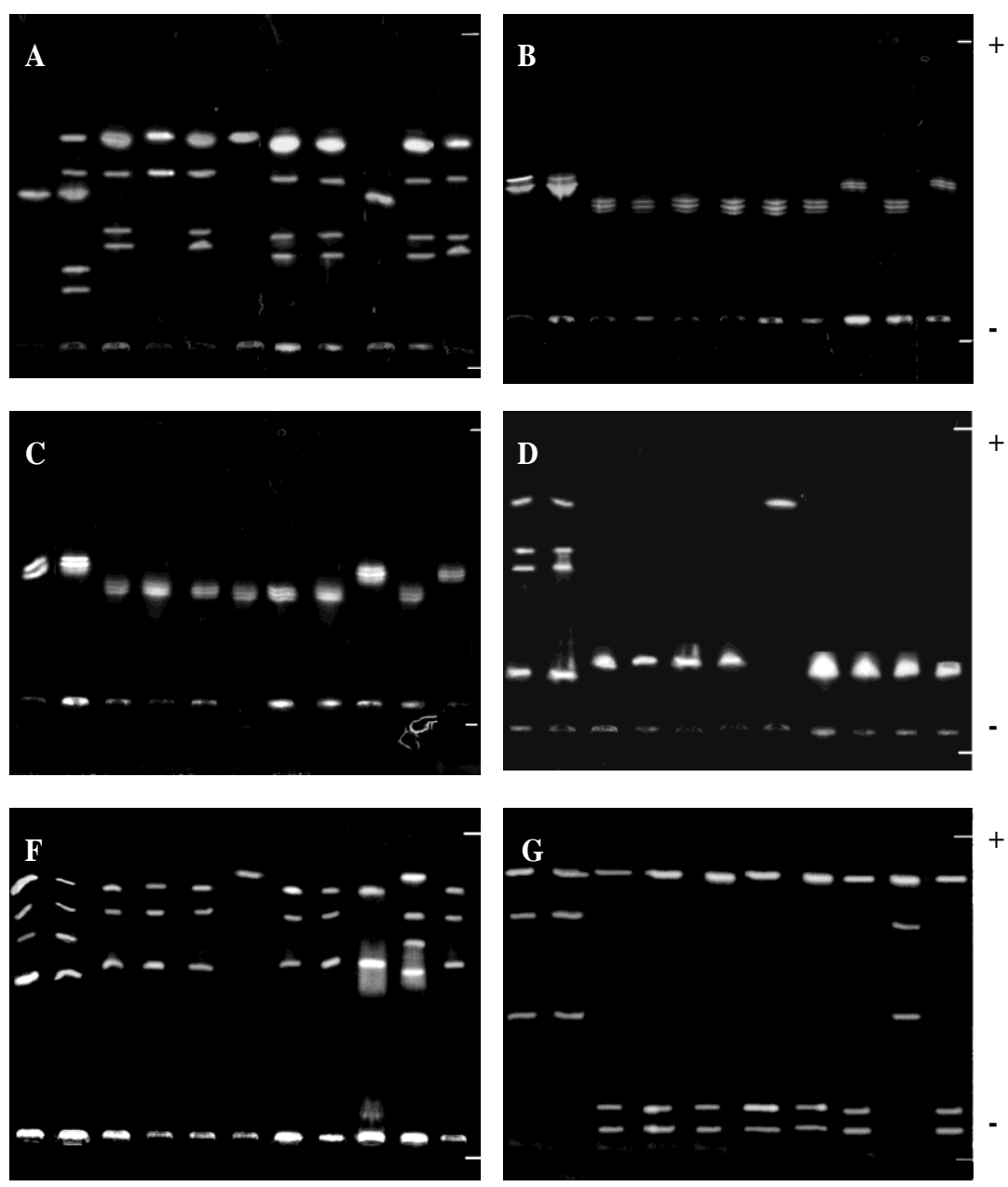

Figura 5:Perfil isoenzimático para los siguientes sistemas: (A) Enzima málico (EM); (B) Glucosa 6-fosfato deshidrogenasa (G6PDH); (C) Glucosa fosfato isomerasa (GPI); (D) Isocitrato deshidrogenasa (IDH); (E) Malato deshidrogenasa (MDH); (F) Superóxido dismutasa (SOD).Organismos: (1) UCM 09; (2) UCM 17; (3) UCM 75; (4) UCM 14; (5) UCM 06; (6) UCM 45; (7) UCM 21; (8) UCM 12; (9) UCM 11; (10) UCM 20; (11) UCM 1 


\subsection{ANÁLISIS DE LOS FRAGMENTOS DEL DNAK OBTENIDOS POR ENDONUCLEASAS}

Otra de las técnicas utilizada para la caracterización ha sido el análisis del ADN del Kinetoplasto, previa digestión con enzimas de digestión. Para ello se purificó el $\mathrm{ADN}_{\mathrm{k}}$ de las tres cepas de referencia y de los ocho aislados estudiados, y se sometieron a digestión con cinco enzimas de restricción (EcoRI, MspI, HindIII, HinfI y BamHI). Posteriormente se sometieron a electroforesis en geles de agarosa al 1.3\%, revelando que el $\mathrm{ADN}_{\mathrm{k}}$ intacto (sin digerir) no puede penetrar en el gel. Sin embargo, tras la digestión los fragmentos de $\mathrm{ADN}_{\mathrm{k}}$ si penetran en el gel, y cuando la digestión es completa, el material genético desaparece totalmente de la parte superior del gel. Todo el $\mathrm{ADN}_{\mathrm{k}}$ ensayado fue digerido en fragmentos de tamaño diferente, esto es evidente si nos fijamos en los perfiles de restricción heterogéneos que se nos muestran en la figura 6.

El modelo de los perfiles de restricción coincidió sólo para las cepas UCM 1 y UCM 6 con la endonucleasa HaeIII (Figura 6 C, líneas 5 y 11). En la figura 2.A se muestran cuatro perfiles diferentes tras la digestión con la endonucleasa BamH I: un grupo con 5 fragmentos (UCM 12 y UCM 11), un segundo grupo con 4 fragmentos (UCM 9, UCM 17, UCM 75, UCM 21 y UCM 1) y el tercer grupo con 2 fragmentos (UCM 12 y UCM 11).

El enzima de restricción EcoRI digirió el $\mathrm{ADN}_{\mathrm{k}}$ en 2 fragmentos, pero con tamaños diferentes, excepto para la UCM 14 (Fig. 6.B, line 4). Se observa que los perfiles son iguales en tamaño en UCM 9, UCM 17, UCM 75, UCM 21 y UCM 1 por una parte, iguales en tamaño en la UCM 6 y UCM 45 por otra, e iguales en tamaño en UCM 12, UCM 11, UCM 20.

El enzima de restricción HinfI (Figura 6.D) muestra unos perfiles de digestión con 4 fragmentos de igual tamaño para las cepas UCM 9, UCM 17, UCM 75, UCM 1 y de tamaño diferente en UCM 14 y UCM 12, el resto de cepas, (UCM 6, UCM 45, UCM 21, UCM 11 y UCM 20) presentan 2 fragmentos de igual tamaño en UCM 6, UCM 45, UCM 21 y de tamaño diferente en UCM 11 y UCM 20. 
De igual manera la digestión con MspI (Figura 6.E) produjo un perfil enzimático con 2 fragmentos de igual tamaño en UCM 9, UCM 17, UCM 75, UCM 21 y UCM 1 y tamaño diferente en UCM 6 y UCM 11. 1 fragmento de igual tamaño en UCM 14 y UCM 45 y diferente en UCM 20 y UCM 6 fragmentos en UCM 12.
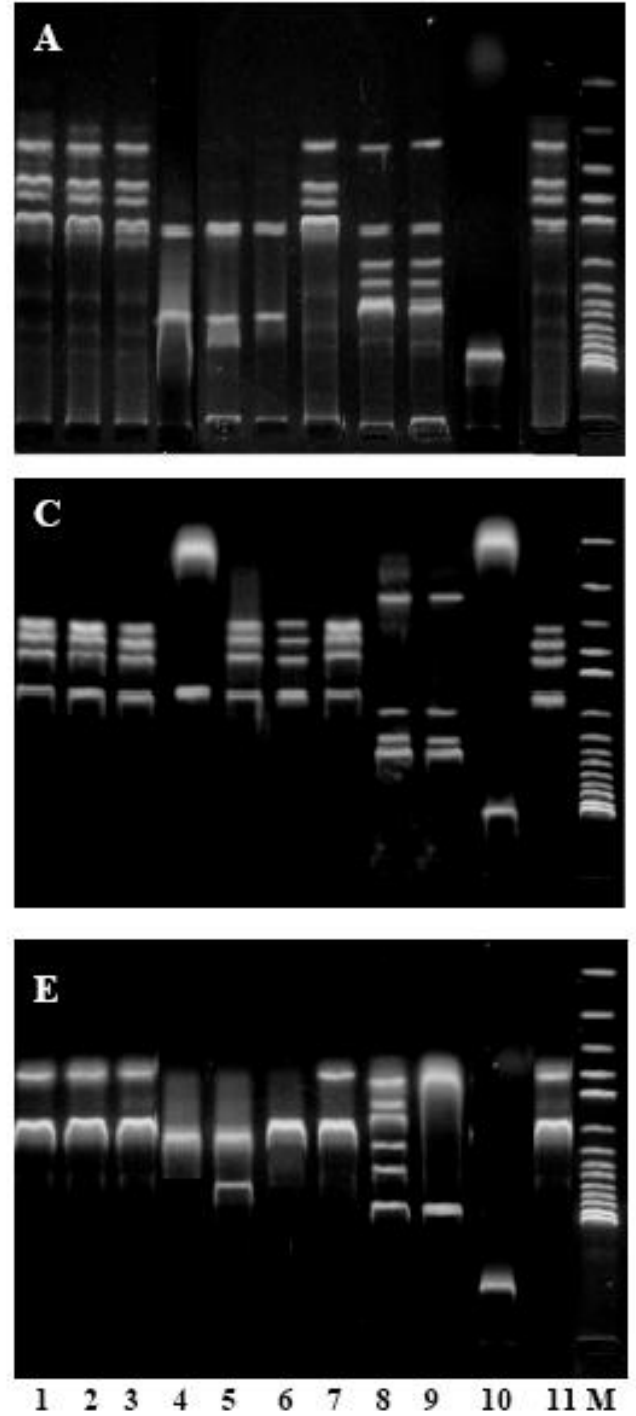
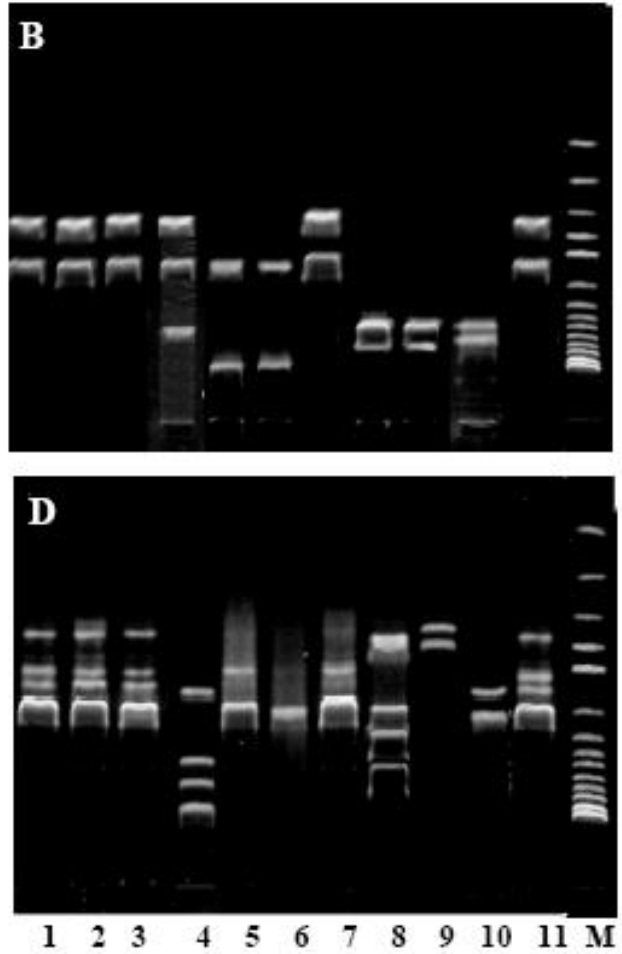

Figura 6: Análisis de restricción con endonucleasas del $\mathrm{AND}_{\mathrm{k}}$ : (A) kDNAs + BamHI; (B) kDNAs + EcoRI; (C) kDNAs + HaeIII; (D) kDNAs + HinfI; y (E) kDNAs + MspI. Lane : (1) UCM 09; (2) UCM 17; (3) UCM 75; (4) UCM 14; (5) UCM 06; (6) UCM 45; (7) UCM 21; (8) UCM 12; (9) UCM 11; (10) UCM 20; (11) UCM 1. (M) Marcador 10000-bp DNA ladder. 


\subsection{PCR y RFLP-HAE.}

La PCR amplificó una parte de los genes de la subunidad pequeña del $\mathrm{RNA}_{\mathrm{r}}$ reflejando una banda de un tamaño aproximadamente 400 pb para las cepas UCM 9, UCM 17, UCM 75, UCM 14, UCM 12 y UCM 20 (Figura 7. Líneas 1, 3, 4, 5, 8, 9,10 у 11), mientras que, para las cepas UCM 45 y UCM 21 amplifico un fragmento de aproximadamente $700 \mathrm{pb}$.

La digestión del producto obtenido tras la amplificación por PCR con la endonucleasa de restricción HaeIII revela 2 perfiles diferentes de RFLP de acuerdo al resultado de la PCR: 4 fragmentos comprendidos entre 150-bp a 400-bp y 3 fragmentos entre 150 y 700-bp.
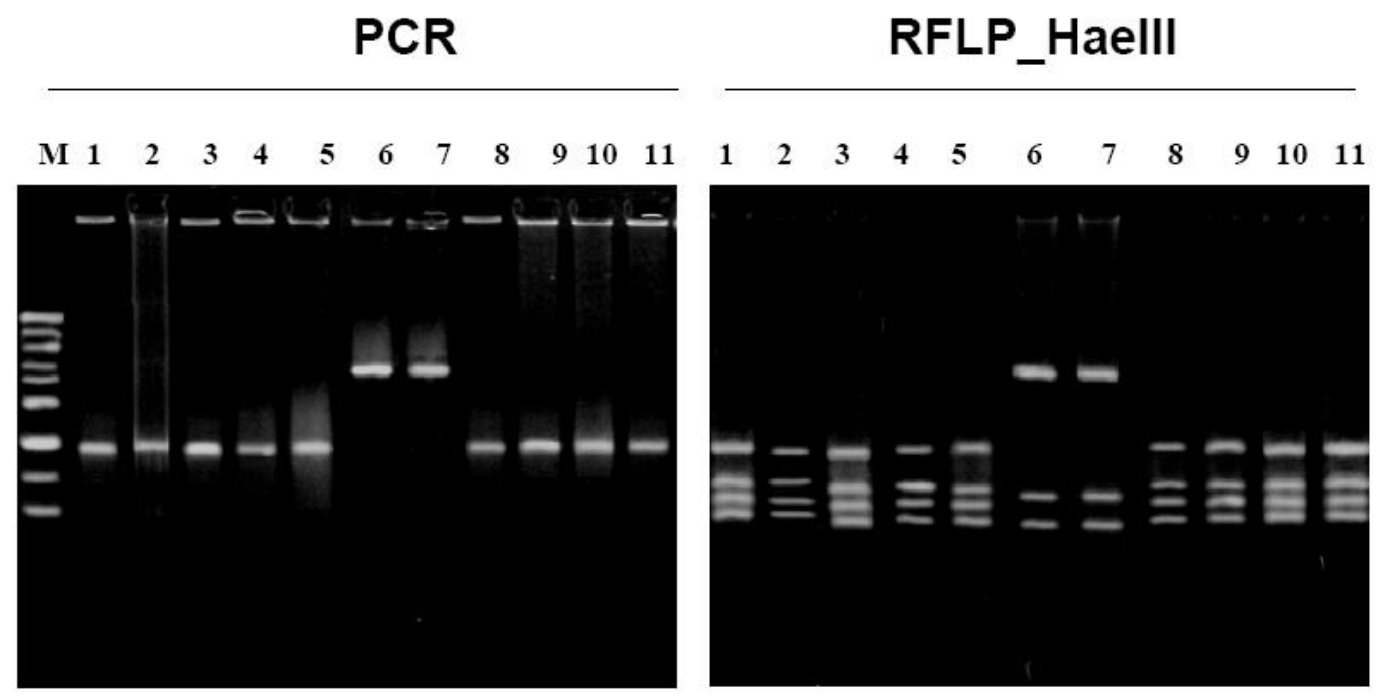

Figura 7: Resultado de la amplificación por PCR de diferentes especies y aislados de Leishmania usando los primers R174 y R758,y posterior digestión de estos productos con la endonucleasa HaeIII, a cada pocillo se le añadió $10 \mu 1$ de muestra. líneas: (1) UCM 09; (2) UCM 17; (3) UCM 75; (4) UCM 14; (5) UCM 06; (6) UCM 45; (7) UCM 21; (8) UCM 12; (9) UCM 11; (10) UCM 20; (11) UCM 1. (M) ladder 1000-pb de peso molecular. 


\section{DISCUSIÓN}

Los perros están considerados como el reservorio clásico para Leishmania infantum, perteneciente al zimodema 1, el cuál es agente etiológico mas común en los países mediterráneos (Gallego et al., 2001; Pratlong et al., 2004).En el presente estudio, los aislados fueron caracterizados con seis enzimas y el estudio estadístico hecho sobre los resultados basándose en las comparaciones de los diferentes modelos isoenzimáticos mostró 2 Clusters:

Cluster 1: UCM 1, UCM 11, UCM 9 y UCM 17.

Cluster 2: UCM 6, UCM 12, UCM 14, UCM 20, UCM 21, UCM 45, UCM 75.

El estudio estadístico realizado sobre los patrones de bandas que se formaron tras la digestión del $\mathrm{ADN}_{\mathrm{k}}$ con cinco enzimas de restricción mostró también 2 Clusters:

Cluster 1: UCM 1, UCM 9, UCM 17, UCM 21 y UCM 75.

Cluster 2: UCM 6, UCM 11, UCM 12, UCM 14, UCM 20 y UCM 45.

El estudio estadístico resultante de los datos mostrados de la técnica PCR, así como los de la RFLP (digestión de los productos resultantes de la PCR con la endonucleasa HAE III) volvió a mostrar 2 Clusters:

Cluster 1: UCM 6, UCM 20 y UCM 45.

Cluster 2: UCM 1, UCM 9, UCM 11, UCM 12, UCM 14, UCM 17, UCM 21 у UCM 75.

Finalmente, el análisis estadístico de todos los resultados juntos nos proporciona la mayor información en cuanto a la identificación y relación filogenética se refiere. En este análisis jerárquico final o dendograma nos agrupa a los aislados en 2 grandes clusters, subdividiendose el segundo cluster en 3 subclusters, en el se puede apreciar 
como se separan las 3 cepas de referencia, todas consideradas pertenecientes al zimodema 1, quedando separadas la UCM 6 de la UCM 1 y UCM 11.

Cluster 1: UCM 1, UCM 9, UCM 17, UCM 21 y UCM 75.

\section{Cluster 2:}

Subcluster 1: UCM 6, UCM 14 y UCM 45

Subcluster 2: UCM 11 y UCM 12.

Subcluster 3: UCM 20.



Figura 8: Dendrograma basado en el análisis individual de cluster (Program StatGraphics version 5.0) 


\section{CONCLUSIONES.}

La identificación y la relación filogenética entre ocho nuevos cepas de Leishmania infantum aisladas de perros en la provincia de Madrid, se establece con el análisis estadístico global de todos los resultados obtenidos por el análisis isoenzimático por medio de seis enzimas diferentes, por el análisis del DNA del kinetoplasto mediante cinco enzimas de restricción y por la técnica PCR, así como los de la RFLP (digestión de los productos resultantes de la PCR con la endonucleasa HAE III). Estos aislados fueron comparados con tres cepas tipificadas como Leishmania infantum zimodemo MON-1. El análisis jerárquico final nos agrupa a los aislados en 2 grandes clusters, en el se puede apreciar como se separan las 3 cepas de referencia, todas consideradas pertenecientes al zimodemo 1, quedando separadas la UCM 6 de la UCM 1 y UCM 11. El cluster primer estaría formado por la cepa de referencia UCM 1 y los aislados UCM9, UCM 17, UCM 21 y UCM 75, subdividiéndose el segundo cluster en 3

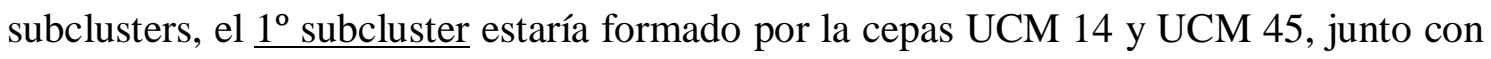

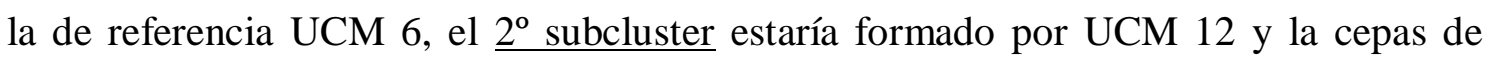
referencia UCM 11 y el $3^{\mathrm{a}}$ subgrupo estaría formado por el aislado UCM 20. 


\section{BIBLIOGRAFÍA}

- Alvar, J. 1997. Las leishmaniasis: de la biología al control. Prevención y control de las zoonosis. Junta de Castilla y León, Zamora. 151

- Bulle, Laurence, M. Jean-Mathieu, B. Montserrat, G. Françoise, G. Montserrat, P. Lee, S. Charles, L. Jaffe, S. José María A. y Renaud P. (2002) Practical Approach for Typing Strains of Leishmania infantum by Microsatellite Analysis. J. Clin. Microbiol. 33: 3391-97.

- Ardehali, S. Sodelghi-Hassanabani, A. Moaddeb, A Abdollanhi, B. Malek-hosseini, Z. y Evan, DA. (1995). The characterization of leishmania from patients whit lymphadenopathy in Shiraz, Iran. Trans. R, Soc. Trop. Med. Hyg. 89-(4), 370-1.

- Ben Abderrazak, S. Guerrini, F. Mathieu-Daude, F. Truc, P. Neubauer, K. Lewiccka, K. Barnabe, C. y Tibayrenc, M. (1993). Isoenzyme electrophoresis for parasite characterization. In: Methods in Molecular Biology (Hyde, J.E., ed), Vol. 21, Chapter 27 pp.361-382. Human Press Inc., Totowa, N.J.

- Beyer, WF. y Fridovich, I. (1987). Assaying for superoxide dismutase activity: Some large consequences of minor changes in conditions. Anal. Biochem. 161: 559-660.

- Biogliolo, AR. Chiari, E,. Silva-Pereira, AA. (1986). A comparative study of enzyme polymorphism in South America. Bra. J. Med. Biol. Res. 19:673-683.

- Bosio, I. (2001). Principios básicos de criobiología. $1^{\circ}$ Congreso ASEBIR. Vol. 18 no 4.

- Botet Fregola, J. y Portús, M. (1993). "La leishmaniasis en la España peninsular. Revisión histórico bibliográfica (1912-1985)". Rev. San. Hig. Púb. 67: 255-266.

- Brown, LM. y Ray, DS. (1997). Cell cycle regulation of RPA1 transcript levels in the trypanosomatid Crithidia fasciculate. Nucl. Acids. Res. 25: 328-9. 
- Cavalier-Smith, T. (2003). "Protist phylogeny and the high-level classification of Protozoa." Eur. J. Protistol. 39: 338-348.

- Chang, K. P. y Dwyer, D. M. (1978). "Leishmania donovani. Hamster macrophage interactions in vitro: cell entry, intracellular survival, and multiplication of amastigotes." J. Exp. Med. 147: 515-30.

- Chang, P. Chaudhuri, G. y Fong, D. (1990). "Molecular determinants of Leishmania virulence." Annu. Rev. Microbiol. 44: 499-529.

- Craig, CF. y Faust, EC. (1951). Clinical Parasitology. Ed. Lea \& Febiger. Philadelphia.

- Crowther, S. Fulton, JD. y Joyner, LP. (1954). "The metabolism of Leishmania donovani in culture." Biochem. J. 56: 182-5.

- Fernández, O. Souto, R. y col. (1998). Brazilian isolates of Trypanosoma cruzi from humans and triatomines classified into two lineales using mini-exon and ribosomal RNA sequences. Am. J. Trop. Med. Hyg. 58(6); pp 807-811.

- Gállego, M. y Riera, C. Las leishmaniasis humanas: Leishmaniasis autóctona por Leishmania infantum http://www.seimc.org/control/revi_Para/leish.htm

- Gallego, M. Pratlong, F. Fisa, R. Riera,C. Rioux, JA. Dedet, JP. y Portus, M. (2001). The life-cycle of Leishmania infantum MON-77 in the Priorat (Catalonia, Spain) involves humans, dogs and sandflies; also literature review of distribution and hosts of L. infantum zymodemes in the Old World. Trans.R.Soc.Trop.Med.Hyg. 95, 3, 269-271.

- Ghosh, DK. Ghosh, AK. Ghosh, KN. y Bhattacharya, A. (1990). Kinetoplastid flagellates: surface-reactive carbohydrates detected by fluorescein-conjugated lectins. J. Paarasitol. Feb, 76(1): 130-3.

- Gibson, M. E. (1983). The identification of kala-azar and the discovery of Leishmania donovani. Med. Hist.27: 203-13. 
- Goçalves, AM. Neheme NS. y Morel, CM. (1984). Trypanosomatid characteritation by schizodeme analysis. In: Genes and Antigens of parasites (A Laboratory Manual) Morel, C.M., Ed, $2^{\text {nd }}$ ed. Fundaçao Oswualdo Cruz, Rio de Janeiro, RJ, Brazil.

- Golfrey, DG. y Kilgour V. (1976). Enzyme electrophoresis in characterizing the causative agent of Gambian Tripanosomiasis. Trans. R. Soc. Trop. Med. Hyg. 71: 217225.

- Granner, DK. y O'Brien, RM. (2001)._Molecular physiology and genetics of NIDDM. Importance of metabolic staging. Diabetes Care. 15 (3):369-95.

- Guzmán-Marín, ES. Zavala-Castro, JE. Acosta-Viana, KY. y Rosado Barrera, ME. (1999). The importante of the caracteritation of Trypanosoma cruzi Straits. Rev. Bromed: Vol 10/ N³/Julio-septiembre.

- Harris, E. Kropp, G. Belli, A. Rodrigez, B. y Agabain, N. (1998). Singlestep multiplex PCR assay for characterization of new world Leishmania complexes. J Clin Microbiol, 36: 1989-1995.

- Higo, H. Yanagi, T. Agatsuma, M. Cruz-Reyes, A. Uyema, N. Monroy, C. Kanbara, H y Tada I. (2000). Genetic structure of Trypanosoma cruzi in American continents: special emphasis on sexual reproduction in Central America. Parasitol. 121 (Pt4): 403408.

- Ibrahim, ME. Evans, DA. Theander, TG. Hassan, AM. y Kharazmi, A. (1995). Diversity among Leishmania isolates from the Sudan: isoenzyme homogeneity of $L$. donovani versus heterogeneity of L.mayor. Trans R. Soc. Trop. Hyg. 89(4): 336-339.

- Kamhawi, S. (2006). "Phlebotomine sand flies and Leishmania parasites: friends or foes?" Trends Parasitol. 22: 439-45.

- Killick-Kendrick, R. Lainson, R. Rioux, JA. y SafJanova, WM. (1986). The taxonomy of Leishmania-like parasites of Reptiles. In: Leishmania. Taxonomie et phylogenèse (Rioux, J. A., ed.). Montpellier, IMEE 143-148. 
- Lainson, R. y Shaw, JJ. (1987). Evolution, classification and geographical distribution. In: The leishmaniases in biology and medicine (Peters, W., KillickKendrick, R., Eds.). London, Academic Press 1-120.

- Lewicka, K. Breniere-Campana, SF. Barnabe, C. Dedet, JP. y Tibayrenc, M, (1995). An isoenzyme survey of Trypanosoma cruzi genetic variability in sylvatic cycles from French Guiana. Exp. Parasitol. 81 (1): 20- 28.

- Lofgren, R. (1950). "The structure of Leishmania tropica as revealed by phase and electron microscopy." J. Bacteriol. 60: 617-25.

- Lucas, CM. Franke, ED. Cachay, MI. Tejada, A. Carrizales, D. y Kreutzer, RD. (1994). Leishmania (Viannia) lainsoni: first isolation in Peru. Am. J. Trop. Med. Hyg. 51(5): 533-537.

- Magill, A.J. (1999). Leishmaniasis. Hunter's Tropical Medicine and emerging infectious diseases. Hunter, G. W. y Strickland, G. T., WB Sanders: 665-679.

- Menezes, DMF. Montijo, CMF. Figueiredo, EM. y Romanha, AJ. (1996). Lectin interaction with Leishmania amazonensis promastigotes. Mem. Inst. Oswualdo Cruz. Vol 91, Suppl.

- Merino, A. y Gamba, G. (2006). Molecular biology in medicine. II. Restriction enzymes. Rev Invest Clin._48(2):159-63.

- Moreira, D. Lopez-Garcia, P. y Vickerman, K. (2004). "An updated view of kinetoplastid phylogeny using environmental sequences and a closer out group: proposal for a new classification of the class Kinetoplastea." Int. J. Syst. Evol. Microbiol. 54: 1861-75.

- Morel, C. Chiari, E. Camargo, EP. Mattei, DM. Romanha, AJ. Simpson, I. (1980). Strains and clones of Trypanosoma cruzi can be caracterized by patterns of restriccions endonuclease products of kinetoplasto DNA minicircles. Proc. Nat. Acad. Sci. 77: 6810-6814. 
- Oliveira, RP. Broude, NE. Macedo, AM. Cantor, CR. Smith, CL. y Pena, SDJ. (1998). Probing the genetic population structure of Trypanosoma cruzi whit polymorphic microsatellites. Proc. Natlt. Acad. Sci. USA 95: 3776-3780.

- Oumeish, OY. (1999). "Cutaneous leishmaniasis: a historical perspective." Clin. Dermatol. 17: 249-54.

- Paoletti, F. y Mocali, A. (1990). Determination of superoxidase dismutase activity by purely Chemicals system. Based on NAD(P)H Oxidation methods in enzymology. Vol. 186. pp 209-265.

- Penin, P. Sánchez-Moreno, M. y de Diego, JA. (1998). Proton Nuclear Magnetic Resonance Analisis of metabolismo end products of the Bolivia strain of Trypanosoma cruzi and three of its clones. Comparative Biochemistry and Physiology-part A, 120 (4) : 571-574.

- Pimenta, PF. Saraiva, EM. Rowton, E. Modi, GB. Garraway, LA. Beverley, SM. Turco, SJ. y Sacks, DL. (1994). "Evidence that the vectorial competence of phlebotomine sand flies for different species of Leishmania is controlled by structural polymorphisms in the surface lipophosphoglycan." Proc. Natlt. Acad. Sci. USA. 91: 9155-9.

- Pratlong, F. Rioux, JA. Marty, P. Faraut-Gambarelli, F. Dereure, J. Lanotte, G. Dedet, JP. (2004). Isoenzymatic analysis of 712 strains of Leishmania infantum in the south of France and relationship of enzymatic polymorphism to clinical and epidemiological features. J. Clin. Microbiol. 42 (9): 4077-4082.

- Rassam, Mb. Al-Mudhaffar, SA. y Chance, ML. (1979). Isoenzyme carateritation of Leishmania species from Iraq. Ann. Trop. Parasitol. 73 (6): 527-34.

- Riou, G y Yot, P. (1977). Heterogenety of the Kinetoplast DNA molecules of Trypanosoma cruzi. Biochem. 16: 2390-2396. 
- Rodríguez, P. Montilla, M. Nicholls, S y col. (1998). Isoenzymatic charateritation of Colombia Straits of Trypanosoma cruzi. Mem. Inst. Oswualdo Cruz. 93(6): 739-740.

- Rogers, ME. Chance, ML. y Bates, PA. (2002). The role of promastigote secretory gel in the origin and transmission of the infective stage of Leishmania mexicana by the sandfly Lutzomyia longipalpis. Parasitol. 124: 495-507.

- Sacks, D. y Kamhawi, S. (2001). Molecular aspects of parasite-vector and vector-host interactions in leishmaniasis. Ann. Rev. Microbiol. 55: 453-83.

- Sánchez-Moreno, M. Lasztity, D. Coppens, I y Opperdoes, FR.(1992). Characteritation of Carbohydrate metabolism and demostration of Glycosomes in a Phytomonas sp. Isolated from Euphorbia characias. Mol. Biochem. Parasitol. 54: 185200.

- Sánchez-Saldaña, L. Sáenz-Anduaga, E. Pancorbo-Mendoza, J. Zegarra-Del-Carpio, R. Garcés-Velasco, N. y Regis-Roggero, A. (2004). "Leishmaniasis." Dermatol. Peruana 14: 82-98.

- Schmidt, GD. y Roberts, LS. (1985). Foundations of Parasitology. Ed. Mosby College. St. Luis.

- Schottelius, J. y Unlenbruck, G. (1984). Intraspecific characteritation of Trypanosome cruzi stocks by the lectins from Triticum vulgaris and Aracchis hypoganea. Zentralbl Bakteriol. Mikrobiol. Hyg. 256:342-346.

- Steindel, M. Carvalho Pinto, CJ. Toma, HK. y Mangia, RHR. (1991). Trypanosoma rangeli Tejera 1920 isolated from a sylvatic rodent (Echimys dasythrix) in Santa Catarina State: First report of this trypanosames in southern Brazil. Mem. Inst. Oswualdo Cruz. 86: 73-79.

- Trager, W. (1953). "The development of Leishmania donovani in vitro at $37^{\circ} \mathrm{C}$; effects of the kind of serum." J. Exp. Med. 97: 177-88. 
- Travi, Bl. Jaramillo, C. Montoya, J. Segura, I. Zea, A. Gonçalves, A. Velez, ID. (1994). Didelphis marsupiales, an important reservoir of Trypanosoma (Schizotrypanum) cruzi and Leishmania (Leishmania) chagasi in Colombia. Am J. Trop. Med. Hyg. 50(5):557-565.

- Van Eys, E. Schoone, N. Kroon, CM. y Ebeling, SB. (1992). Sequence analysis of small subunit ribosomal RNA genes and its use for detection and identification of leishmania parasites. Mol. Biochem. Parasitol. 51: 133-142.

- Volpini, AC. Passos, VM. Oliveira, GC. Romanha, AJ. (2004). PCR-RFLP to identify Leishmania (Viannia) brazilensis and L. (Leishmania) amazonensis causing American cutaneus Leishmaniasis. Acta Trop. 90, 31-37. 